This document was prepared in conjunction with work accomplished under Contract No. DE-AC09-96SR18500 with the U. S. Department of Energy.

\title{
DISCLAIMER
}

This report was prepared as an account of work sponsored by an agency of the United States Government. Neither the United States Government nor any agency thereof, nor any of their employees, nor any of their contractors, subcontractors or their employees, makes any warranty, express or implied, or assumes any legal liability or responsibility for the accuracy, completeness, or any third party's use or the results of such use of any information, apparatus, product, or process disclosed, or represents that its use would not infringe privately owned rights. Reference herein to any specific commercial product, process, or service by trade name, trademark, manufacturer, or otherwise, does not necessarily constitute or imply its endorsement, recommendation, or favoring by the United States Government or any agency thereof or its contractors or subcontractors. The views and opinions of authors expressed herein do not necessarily state or reflect those of the United States Government or any agency thereof. 


\section{MEASUREMENTS OF FLAMMABLE GAS GENERATION FROM SALTSTONE CONTAINING ACTUAL TANK 48H WASTE (INTERIM REPORT)}

A.D. Cozzi, D.A. Crowley, J.M. Duffey, R.E. Eibling, T.M. Jones, A.R. Marinik, J.C. Marra, and J.R. Zamecnik

June 2005

Immobilization Technology Section Savannah River National Laboratory Aiken, SC 29808

Prepared for the U.S. Department of Energy Under Contract Number DEAC09-96SR18500

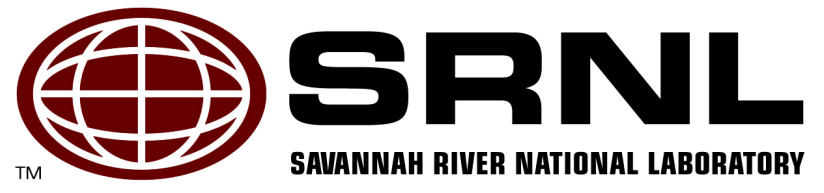


WSRC-TR-2005-00256

Revision 0

\section{DISCLAIMER}

This report was prepared by Westinghouse Savannah River Company (WSRC) for the United States Department of Energy under Contract No. DE-AC09-96SR18500 and is an account of work performed under that contract. Neither the United States Department of Energy, nor WSRC, nor any of their employees makes any warranty, expressed or implied, or assumes any legal liability or responsibility for the accuracy, completeness, or usefulness, of any information, apparatus, or product or process disclosed herein or represents that its use will not infringe privately owned rights. Reference herein to any specific commercial product, process, or service by trademark, name, manufacturer or otherwise does not necessarily constitute or imply endorsement, recommendation, or favoring of same by WSRC or by the United States Government or any agency thereof. The views and opinions of the authors expressed herein do not necessarily state or reflect those of the United States Government or any agency thereof.

\section{Printed in the United States of America \\ Prepared For \\ U.S. Department of Energy}


Key Words: Saltstone

Tetraphenylborate

Tank 48

Benzene

Retention: Permanent

\section{MEASUREMENTS OF FLAMMABLE GAS GENERATION FROM SALTSTONE CONTAINING ACTUAL TANK 48H WASTE (INTERIM REPORT)}

A.D. Cozzi, D.A. Crowley, J.M. Duffey, R.E. Eibling, T.M. Jones, A.R. Marinik, J.C. Marra, and J.R. Zamecnik

June 2005

Immobilization Technology Section Savannah River National Laboratory Aiken, SC 29808

Prepared for the U.S. Department of Energy Under Contract Number DEAC09-96SR18500

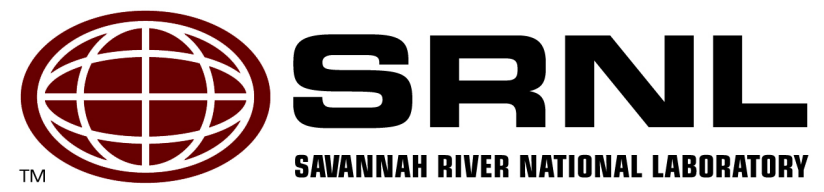


WSRC-TR-2005-00256

Revision 0

\section{REVIEWS AND APPROVALS}

\section{AUTHORS:}

Ala Con

A.D. Cozzi, Immobilization Technology Section

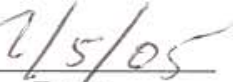

Q.m. Vufkez

J.M. Duffey, Actinide trechnology Section

russel $2 \%$ iblens.

R.E. Eibling, Immobilization Technology Section

Mmitty $\mathrm{r}$ jove

T.M. Jones, Immobilization Technology Section

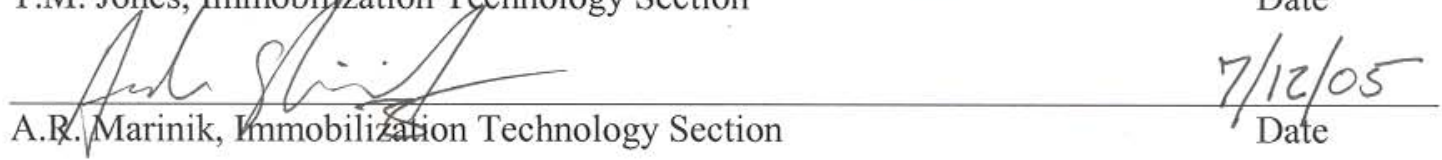

Demer C. Whum

L. Marra, Immobilization Technology Section

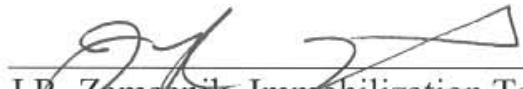

J.R. Zamecnik, Immobilization Technology Section

Date

$7 / 12 / 05$

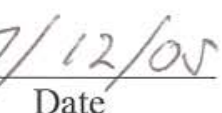

Date

$7 / 12 / 05$

Date

Date

\section{TECHNICAL REVIEWERS:}

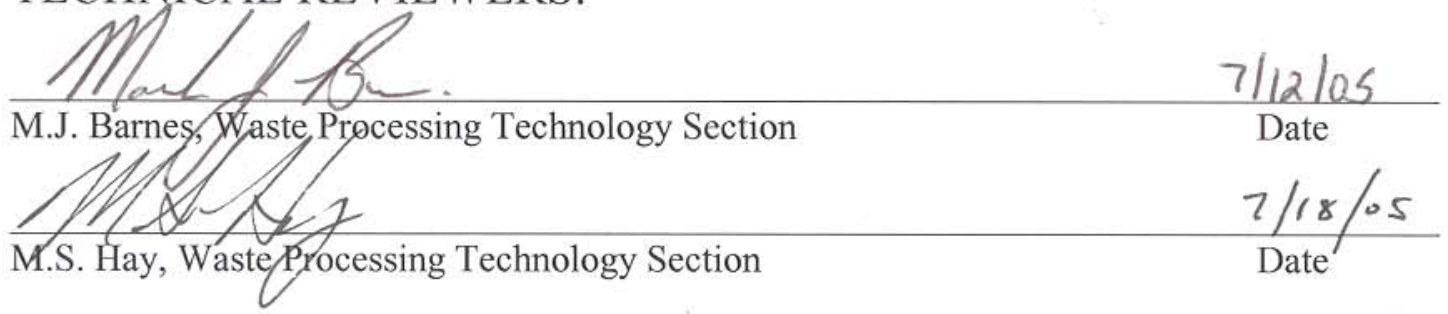

\section{APPROVERS}

\section{Ew tretrenkur}

E. W. Holtzscheiter, Manager, Immobilization Technology Section
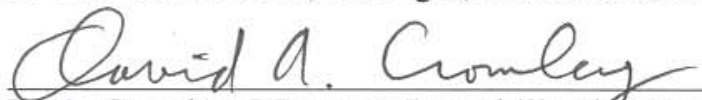

D. A. Crowley, Manager, Immobilization Technology \& Business Development/Date
Date

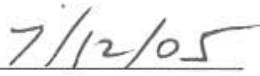

Date

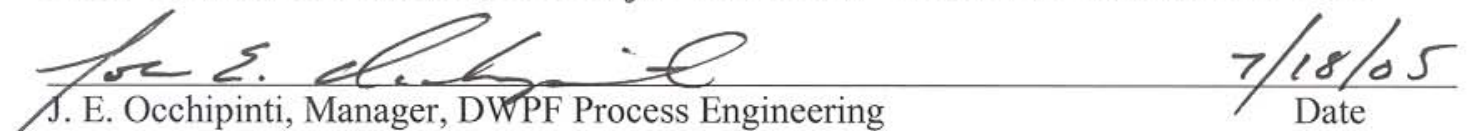


WSRC-TR-2005-00256

Revision 0

\section{EXECUTIVE SUMMARY}

The Savannah River National Laboratory was tasked with determining the benzene release rates in saltstone prepared with tetraphenylborate (TPB) concentrations ranging from $30 \mathrm{mg} / \mathrm{L}$ to 3000 $\mathrm{mg} / \mathrm{L}$ in the salt fraction and with test temperatures ranging from ambient to $95{ }^{\circ} \mathrm{C}$. ${ }^{1}$ Defense Waste Processing Facility Engineering (DWPF-E) provided a rate of benzene evolution from saltstone of $2.5 \mu \mathrm{g} / \mathrm{L} / \mathrm{h}$ saltstone $(0.9 \mu \mathrm{g} / \mathrm{kg}$ saltstone $/ \mathrm{h}[1.5 \mu \mathrm{g} / \mathrm{kg}$ saltstone $/ \mathrm{h} \times 60 \%])$ to use as a Target Rate of Concern (TRC). ${ }^{2}$

The evolution of benzene, toluene, and xylenes from saltstone containing actual Tank $48 \mathrm{H}$ salt solution has been measured as a function of time at several temperatures and concentrations of TPB. The Tank $48 \mathrm{H}$ salt solution was aggregated with a DWPF recycle simulant to obtain the desired TPB concentrations in the saltstone slurry.

The purpose of this interim report is to provide DWPF-E with an indication of the trends of benzene evolution. The data presented are preliminary; more data are being collected and may alter the preliminary results. A more complete description of the methods and materials will be included in the final report. The benzene evolution rates approximately follow an increasing trend with both increasing temperature and TPB concentration. The benzene release rates from 1000 $\mathrm{mg} / \mathrm{L} \mathrm{TPB}$ at $95{ }^{\circ} \mathrm{C}$ and $3000 \mathrm{mg} / \mathrm{L} \mathrm{TPB}$ at $75{ }^{\circ} \mathrm{C}$ and $95{ }^{\circ} \mathrm{C}$ exceeded the recovery-adjusted 0.9 $\mu \mathrm{g} / \mathrm{kg}$ saltstone/h TRC $(2.5 \mu \mathrm{g} / \mathrm{L}$ saltstone/h), while all other conditions resulted in benzene release rates below this TRC. The toluene evolution rates for several samples exceeded the TRC initially, but all dropped below the TRC within 2-5 days. The toluene emissions appear to be mainly dependent on the fly ash and are independent of the TPB level, indicating that toluene is not generated from TPB. 


\section{TABLE OF CONTENTS}

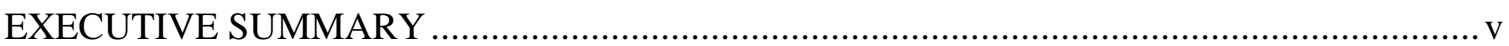

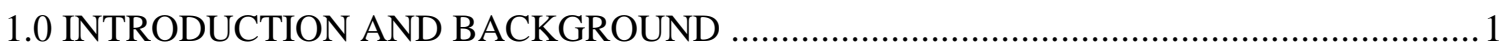

2.0 APPROACH

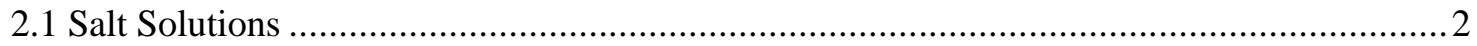

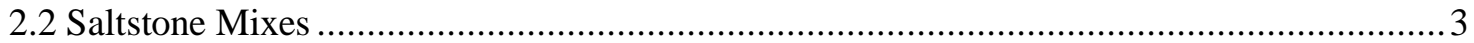

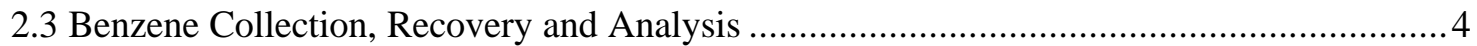

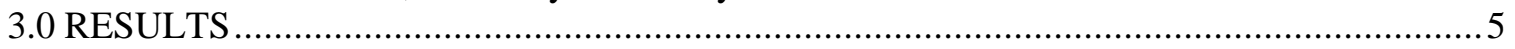

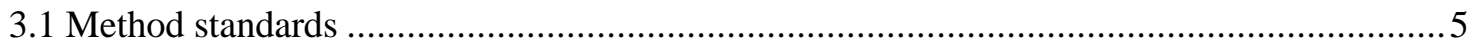

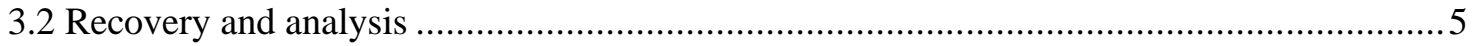

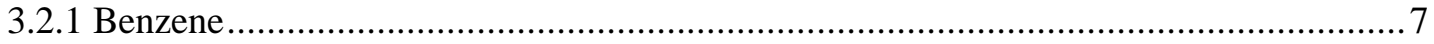

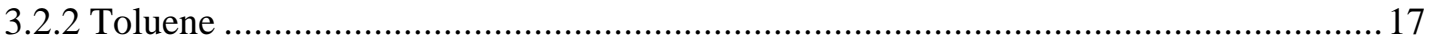

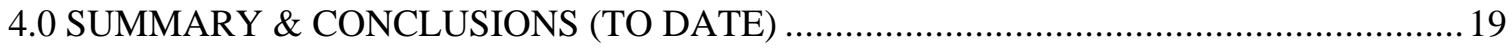

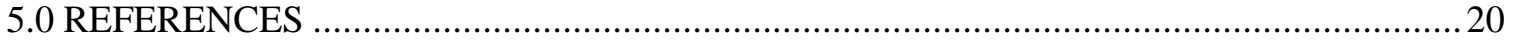




\section{LIST OF FIGURES}

Figure 3-1. Graphic representation of integrated (averaged) release rate data. ...........................6

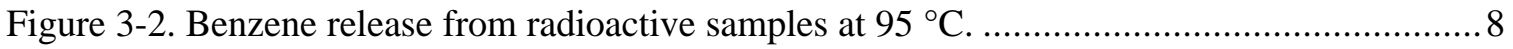

Figure 3-3. Results of Figure 3-2 expanded to show more detail. ........................................ 9

Figure 3-4. Benzene release of radioactive samples with different surface areas........................9

Figure 3-5. Comparison of benzene release from radioactive and simulant tests at $95{ }^{\circ} \mathrm{C}$,

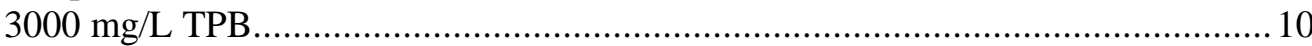

Figure 3-6. Comparison of benzene release from radioactive and simulant tests at $95{ }^{\circ} \mathrm{C}$,

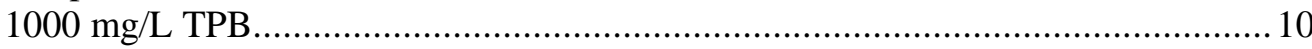

Figure 3-7. Comparison of benzene release from radioactive and simulant tests at $95{ }^{\circ} \mathrm{C}$, $30 \mathrm{mg} / \mathrm{L} \mathrm{TPB}$.

Figure 3-8. Comparison of benzene release from "blanks" at $95{ }^{\circ} \mathrm{C}$ to vessels containing $30 \mathrm{mg} / \mathrm{L}$ TPB

Figure 3-9. Benzene release from vessels at $75{ }^{\circ} \mathrm{C}$ containing TPB.

Figure 3-10. Comparison of benzene release from radioactive and simulant tests at $75{ }^{\circ} \mathrm{C}$, $3000 \mathrm{mg} / \mathrm{L}$ TPB

Figure 3-11. Comparison of benzene release from radioactive and simulant tests at $75{ }^{\circ} \mathrm{C}, 1000 \mathrm{mg} / \mathrm{L} \mathrm{TPB}$.

Figure 3-12. Comparison of benzene release from radioactive and simulant tests at $75{ }^{\circ} \mathrm{C}$, $30 \mathrm{mg} / \mathrm{L} \mathrm{TPB}$.

Figure 3-13. Comparison of benzene release from "blank" at $75^{\circ} \mathrm{C}$ to vessels containing $30 \mathrm{mg} / \mathrm{L}$ TPB.

Figure 3-14. Benzene release from vessels at $25^{\circ} \mathrm{C}$ containing TPB

Figure 3-15. Comparison of benzene release from radioactive and simulant tests at $25^{\circ} \mathrm{C}$, $3000 \mathrm{mg} / \mathrm{L}$ TPB.

Figure 3-16. Comparison of benzene release from radioactive and simulant tests at $25{ }^{\circ} \mathrm{C}$, $1000 \mathrm{mg} / \mathrm{L} \mathrm{TPB}$.

Figure 3-17. Comparison of benzene release from radioactive and simulant tests at $25^{\circ} \mathrm{C}$, $30 \mathrm{mg} / \mathrm{L}$ TPB.

Figure 3-18. Comparison of benzene release from "blanks" at $25{ }^{\circ} \mathrm{C}$ to vessels containing $30 \mathrm{mg} / \mathrm{L}$ TPB.

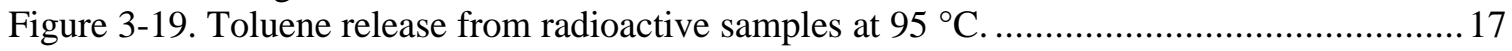

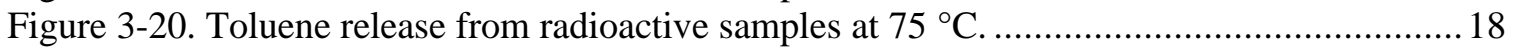

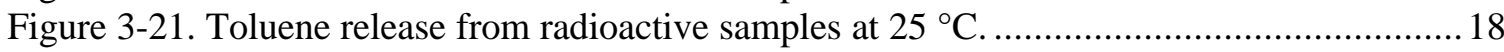




\section{LIST OF TABLES}

Table 2-1. Composition of DWPF Recycle Simulant. .......................................................... 2

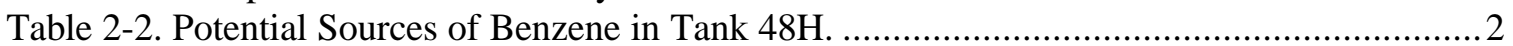

Table 2-3. Calculated Composition and Properties of Salt Solutions. ........................................ 3

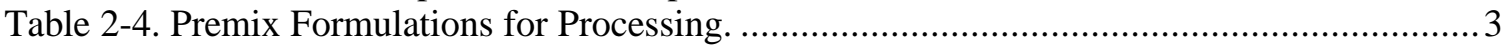

Table 2-5. Matrix of Blend TPB Concentrations and Test Temperatures.................................... 3 


\title{
LIST OF ACRONYMS
}

\author{
ADS Analytical Development Section \\ CLFL Composite Lower Flammable Limit \\ DWPF Defense Waste Processing Facility \\ FID flame ionization detector \\ GC gas chromatograph \\ GCMS gas chromatograph - mass spectrometer \\ GGBFS ground granulated blast furnace slag \\ ID inner diameter \\ KTPB potassium tetraphenylborate \\ NIOSH National Institute for Occupational Safety and Health \\ SRNL Savannah River National Laboratory \\ TPB Tetraphenylborate \\ TRC Target rate of concern
}


WSRC-TR-2005-00256

Revision 0

\subsection{INTRODUCTION AND BACKGROUND}

The operating strategy for processing at the Z-Area Saltstone Facility is projected to result in elevated temperatures in the saltstone vaults over a period of months. This strategy resulted in a review of documentation for the production of benzene via the decomposition of potassium tetraphenylborate (KTPB) solids at elevated temperatures for an extended period of time. Initial review indicates that benzene and other flammable gases could accumulate in the vault vapor space with this proposed operating strategy. The current Z-Area (Saltstone) Safety Basis does not postulate an explosion in the vaults, and therefore, the Safety Basis does not restrict vault temperatures or tetraphenylborate (TPB) concentrations relative to a vault explosion.

An evaluation of prior saltstone grout production confirmed that previous facility operation has not resulted in elevated grout temperatures for extended periods of time (maximum temperature observed $51{ }^{\circ} \mathrm{C}$ and peak temperatures lasted for days rather than months). This review, combined with previous benzene measurements in the vault cells, provides the basis for the position that there is no imminent hazard.

The SRNL was tasked ${ }^{1}$ with determining the benzene release rates in Saltstone grout prepared with TPB concentrations ranging from $30 \mathrm{mg} / \mathrm{L}$ to $3000 \mathrm{mg} / \mathrm{L}$ in the salt fraction and test temperatures ranging from ambient to $95{ }^{\circ} \mathrm{C}$. The request included determination of the effect of surface area to volume ratio on the benzene release rate.

A literature review ${ }^{3}$ summarizing previous work on benzene release and leach results provided the following conclusions:

- Data from past studies of benzene generation from saltstone samples containing TPB and TPB decomposition products should be used with caution due to the large uncertainty associated with the data.

- The average benzene generation rates, measured over the total duration of a test, span from $<0.1$ to $140 \mu \mathrm{g} / \mathrm{hr}$ per liter of saltstone in the reviewed studies. The peak rates, from individual measurement periods during the tests, range from $<0.1$ to $390 \mu \mathrm{g} / \mathrm{hr}$ per liter of saltstone. However, distinguishing what constitutes a statistically significant difference in rate proves difficult due to the high uncertainty present in the data.

- Results of past studies suggest that the evolution of benzene from saltstone samples may show some temperature dependence with rates increasing with temperature. The change in benzene generation rate as a function of temperature cannot be quantified from the available data. The data also suggests that high peak rates may occur sooner when saltstone samples have been cured at higher temperature.

A multi-stage approach is being used to meet these objectives. In the first stage, several potential methodologies for the collection, recovery and analysis of benzene were evaluated. Stage II is ongoing and entails demonstrating the methodology selected in Stage I with simulant materials. Preliminary data for Stage II testing was reported previously. ${ }^{4}$ Preliminary test results of saltstone prepared with actual Tank $48 \mathrm{H}$ material as the source of TPB are presented in this report. Results of the surface area to volume (of saltstone) tests (generation vs. retention) will be discussed in the combined final report. Stage IV studies will investigate other volatile organics that may be emitted during curing and will be discussed in a separate report. 
WSRC-TR-2005-00256

Revision 0

\subsection{APPROACH}

The method to collect and analyze benzene selected from Stage I was to purge the head space of vessels containing saltstone and capture the benzene on a carbon bed. ${ }^{5}$ The benzene is subsequently desorbed and analyzed using a gas chromatograph (GC) with a flame ionization detector (FID). This method was also determined to be applicable for the collection and analysis of toluene and xylene.

\subsection{Salt Solutions}

The Defense Waste Processing Facility (DWPF) recycle simulant targeted the average sodium and the maximum anion and mercury content of the Tank $23 \mathrm{H}$ and Tank $24 \mathrm{H}$ samples taken 100 inches from the tank bottoms as reported by Swingle. ${ }^{6}$ Table 2-1 provides the composition of the DWPF recycle simulant based on the major components listed in Reference 6 . The customer also requested a $2 \mathrm{mg} / \mathrm{L}$ spike of palladium into the salt solution. ${ }^{7}$ The Tank $48 \mathrm{H}$ waste is from a sample taken in 2005. Table 2-2 lists the potential sources of benzene from the Tank $48 \mathrm{H}$ material based on analysis of a previous sample. ${ }^{8}$ Table 2-3 shows the physical properties of the two salt solution and the calculated properties of the resulting blends used for this study. The different TPB concentrations are achieved via the aggregation of the Tank $48 \mathrm{H}$ material with the DWPF recycle simulant.

Table 2-1. Composition of DWPF Recycle Simulant. ${ }^{9}$

\begin{tabular}{||c|c|c|c|c||}
\hline Compound & g/L & & Component & M \\
\hline $\mathrm{NaNO}_{2}$ & 21.734 & & $\mathrm{Na}$ & 0.95 \\
\hline $\mathrm{NaNO}_{3}$ & 5.219 & & $\mathrm{NO}_{2}{ }^{-}$ & 0.32 \\
\hline $\mathrm{NaOH}$ & 17.399 & $\mathrm{NO}_{3}^{-}$ & 0.06 \\
\hline $\mathrm{Na}_{2} \mathrm{CO}_{3}$ & 7.419 & & $\mathrm{OH}^{-}$ & 0.44 \\
\hline $\mathrm{Pd}$ solution $(15.27 \%)^{\mathrm{a}}$ & 0.013 & & $\mathrm{CO}_{3}{ }^{2-}$ & 0.07 \\
\hline $\mathrm{Hg}\left(\mathrm{NO}_{3}\right)_{2} \mathrm{XH}_{2} \mathrm{O}$ & $24.8 \mathrm{mg} / \mathrm{L}$ & & $\mathrm{Hg}$ & $14.5 \mathrm{mg} / \mathrm{L}$ \\
\hline Total & 51.771 & & & \\
\hline & & & & \\
\hline $\mathrm{Wt} \%$ solids & $5.2 \%$ & & & \\
\hline
\end{tabular}

${ }^{\mathrm{a}} \mathrm{Pd}$ solution is palladium nitrate in nitric acid.

Table 2-2. Potential Sources of Benzene in Tank $48 \mathrm{H}^{8}$

\begin{tabular}{||c|c|c||}
\hline Component & Compound & g/L \\
\hline $\begin{array}{c}\text { Tetraphenylborate } \\
\text { a }\end{array}$ & $\left(\mathrm{C}_{6} \mathrm{H}_{5}\right)_{4} \mathrm{~B}^{-}$ & 18.8 \\
Potassium Tetraphenylborate & $\left(\mathrm{C}_{6} \mathrm{H}_{5}\right)_{4} \mathrm{BK}$ & 21.1 \\
\hline Diphenylmercury & $\left(\mathrm{C}_{6} \mathrm{H}_{5}\right)_{2} \mathrm{Hg}$ & $\mathrm{NM}$ \\
\hline Phenol & $\mathrm{C}_{6} \mathrm{H}_{5} \mathrm{OH}$ & 0.97 \\
\hline Biphenyl & $\left(\mathrm{C}_{6} \mathrm{H}_{5}\right)_{2}$ & 0.63 \\
\hline Benzene & $\mathrm{C}_{6} \mathrm{H}_{6}$ & 0.056 \\
\hline \multicolumn{3}{|l}{} \\
\hline
\end{tabular}

NM-Not measured

${ }^{a}$ Added to Tank $48 \mathrm{H}$ as sodium compound. Potassium compound precipitated during treatment of the tank. 
WSRC-TR-2005-00256

Revision 0

Table 2-3. Calculated Composition and Properties of Salt Solutions.

\begin{tabular}{||c|c|c|c|c|c||}
\hline \hline Material & TPB & \multicolumn{2}{|c|}{ Wt. \% Solids } & Density & Mercury \\
\hline & $(\mathrm{mg} / \mathrm{L})$ & Undissolved & Total & $(\mathrm{g} / \mathrm{mL})$ & $(\mathrm{mg} / \mathrm{L})$ \\
\hline Tank 48H ${ }^{10}$ & 21000 & NM & 20.2 & 1.165 & NM \\
\hline $\begin{array}{c}\text { DWPF Recycle } \\
\text { simulant }\end{array}$ & 0 & $<1$ & 5.09 & 1.039 & $14.56($ Tank $24 \mathrm{H})$ \\
\hline $\begin{array}{c}\text { Tank 48H + } \\
\text { DWPF Recycle }\end{array}$ & 30 & NM & 5.1 & 1.04 & 14.5 \\
\cline { 2 - 6 } & 1000 & NM & 5.9 & 1.04 & 14.3 \\
\cline { 2 - 6 } & 3000 & NM & 7.4 & 1.06 & 13.8 \\
\hline
\end{tabular}

NM-not measured

\subsection{Saltstone Mixes}

Saltstone grout was prepared using the salt solutions described previously and premix materials obtained from the Saltstone Processing Facility. Table 2-4 lists the premix composition and the water to premix ratios. The water to premix ratio is defined as the ratio of the mass of evaporable water from the waste $\left(\right.$ at $\sim 110{ }^{\circ} \mathrm{C}$ ) to the combined mass of cement, slag, and fly ash. For the purposes of processing, fixed concentrations $(0.25 \mathrm{wt} \%$ of blended salt solution $)$ of set retarder * and antifoam ${ }^{\dagger}$ were added. The amount of set retarder and antifoam used are based on recommendations made in previous testing. ${ }^{11}$ Table $2-5$ lists the test matrix for variables tested. This resulted in nine TPB-temperature combinations investigated.

Table 2-4. Premix Formulations for Processing.

\begin{tabular}{||c|c||}
\hline \hline Premix & Water/Premix \\
\hline $\begin{array}{c}45 \% \text { Class F Fly Ash (FA) } \\
\text { 45\% GGBFS } \text { GSlag) }^{\text {10\% Cement }}\end{array}$ & 0.63 \\
\hline
\end{tabular}

${ }^{\mathrm{a}}$ Ground granulated blast furnace slag

Table 2-5. Matrix of Blend TPB Concentrations and Test Temperatures.

\begin{tabular}{||c|c|}
\hline TPB (mg/L) & Curing Temperature $\left({ }^{\circ} \mathbf{C}\right)$ \\
\hline 30 & Ambient \\
1000 & 75 \\
3000 & 95 \\
\hline
\end{tabular}

To ensure that all of the TPB was incorporated into each batch, individual Tank $48 \mathrm{H}$ aliquots were taken from a larger sample for each saltstone mix. For example, to prepare the salt solution for the $3000 \mathrm{mg} / \mathrm{L}$ samples for the $95{ }^{\circ} \mathrm{C}$ test, a $71.444 \mathrm{~mL}$ Tank $48 \mathrm{H}$ aliquot was aggregated with $382.1 \mathrm{~mL}$ of DWPF recycle simulant in a blender to make a salt solution with the desired TPB concentration. Premix was added and the mix was blended for one minute, visually inspected, and blended for an additional two minutes. The resulting saltstone slurry was poured into three vessels. Each vessel contained approximately 340 grams of saltstone. This process was repeated for each of the test temperatures. Each of the TPB levels (30, 1000, and $3000 \mathrm{mg} / \mathrm{L}$ referred to in the graphs as L, M, and $\mathrm{H}$, respectively (low, medium, high)) was tested at each temperature in triplicate (replicates a, b, c). Duplicate blanks of simulant saltstone that contained no TPB were also placed in the $95{ }^{\circ} \mathrm{C}$ oven and at ambient temperature. A single blank was used in the $75{ }^{\circ} \mathrm{C}$

\footnotetext{
* W.R. Grace, Daratard 17

${ }^{\dagger}$ Dow-Corning, Q2-3183A
} 
oven. Two standard vessels that were periodically charged with a known amount of benzene standard were also placed in the $95{ }^{\circ} \mathrm{C}$ oven. The vessels were purged, the benzene recovered, and the vessels recharged with benzene approximately once a week to help determine the effectiveness of the sampling technique.

\subsection{Benzene Collection, Recovery and Analysis}

The collection, recovery and analysis of the flammable gases generally follow the National Institute for Occupational Safety and Health (NIOSH) method 1501 for benzene sampling with some modifications to accommodate the experimental set up. ${ }^{5}$ The methodology is identical to that reported in Reference 4. 
WSRC-TR-2005-00256

Revision 0

\subsection{RESULTS}

The release rates of benzene, toluene, and xylenes from saltstone containing actual Tank $48 \mathrm{H}$ salt solution were measured as a function of time at several temperatures. Experiments were run at the three temperatures 95,75 , and $25^{\circ} \mathrm{C}$. Each TPB level was tested at each temperature in triplicate.

\subsection{Method standards}

The recovery of benzene injected into empty vessels was measured. The average benzene recovery was not acceptable. The reduced recovery is believed to be due to either restriction in the flow through the vessels or to the difficulty in handling and injecting small quantities of benzene in the shielded cells rather than on the sampling methodology. Based on this assumption, the approximated recovery of $60 \%$ obtained in the simulant testing will be used in this interim report, with the caveat that a lower recovery factor may be more appropriate. This determination will be deferred to the final report when more recovery data is available.

\subsection{Recovery and analysis}

The sampling frequency for each vessel was adjusted so that measurable quantities of benzene would be collected on the carbon sampling tubes. The majority of the samples collected provided results within the linear calibration range of the GC. In a small percentage of samples cases, the amounts collected were much higher than anticipated and the presence of benzene on the second bed of the sampling tube indicated that the first section was saturated. The front of the tube is considered saturated when $25 \%$ of the total benzene is accounted for in the back half of the tube. ${ }^{5}$ When there is sufficient benzene on the second bed to declare the front saturated, there is then the possibility that not all of the benzene has been collected. However, some samples may have been so concentrated the analysis by GC resulted in saturating the detector such that the actual amount was higher than what was measured. These few samples will be reanalyzed with a greater dilution factor prior to the final report. A few initial samples had benzene on the second bed due to water from the vessels being blown up through the sample line into the sampling tube. These samples will be flagged in the final report.

Results are reported in units of $\mu \mathrm{g}$ flammable gas $/ \mathrm{kg}$ saltstone $/ \mathrm{h}$, where the flammable gas is either benzene $(\varphi)$ or toluene. Analysis of xylene concentration data has not yet been done, but most values appear to be significantly lower than the benzene concentrations. To get the true flammability of a particular offgas mixture, the composite lower flammable limit (CLFL) of the mixture must be used, so the concentrations (release rates) of all flammable species are needed.

The customer has supplied a Target Rate of Concern (TRC) for flammable gas release of $2.5 \mu \mathrm{g} / \mathrm{L}$ saltstone grout/h at which tentative calculations indicate that positive ventilation of the saltstone vaults would be required. ${ }^{2}$ This release rate of $2.5 \mu \mathrm{g} / \mathrm{L}$ saltstone/h is approximately equivalent to $1.5 \mu \mathrm{g} / \mathrm{kg}$ saltstone $/ \mathrm{h}$ given an approximate density of saltstone grout of $1.7 \mathrm{~kg} / \mathrm{L}$ (estimated from a representative sample of saltstone). Because the density is estimated, the final values will be slightly different as the final densities will most likely be slightly different. The measured release rates should be divided by the recovery factor to give a more conservative rate, but for this preliminary report, the TRC was instead decreased by the recovery factor, which accomplishes the same purpose. In the final report, the measured rates will be adjusted for the recovery factor rather than the TRC. Applying the $60 \%$ recovery factor to this rate gives a more conservative TRC of $0.9 \mu \mathrm{g} / \mathrm{kg}$ saltstone/h. (Technically, the evolution rates should be divided by $60 \%$ rather than reducing the TRC, but the relative comparison will be the same. The rates will be adjusted properly in the final report.) Also, these rates are based on an estimate of the mass of saltstone 
since the final cured mass cannot be measured until the tests are complete. The final masses may be less than the as-cast masses. Therefore, the release rates may be slightly higher than reported here.

The data reported in the following graphs show the mean values of the benzene release rate over specific time intervals. The actual measurements made are the total amount of benzene generated during the time interval that the sampling tube is installed on the vessel. Therefore, the amount of benzene measured is the amount evolved integrated over the time interval. Because the sample is integrated, the resulting rate (amount collected / collection time interval) is the average rate over the time interval. Therefore, to properly display this information, this average rate should be plotted as a horizontal line over the time interval of the sample. An example of plotting like this is shown in . Plotting as horizontal lines indicates that only the average release rate over the time interval is known; the actual rate could have fluctuated significantly over the time interval, but only the average is known. Because it is very difficult to plot all of the data in this way (horizontal line averages), each release rate average (over a time interval) was instead plotted as a single point at the average time of the interval. This way of plotting is compared to the horizontal line average plot in Figure 3-1.

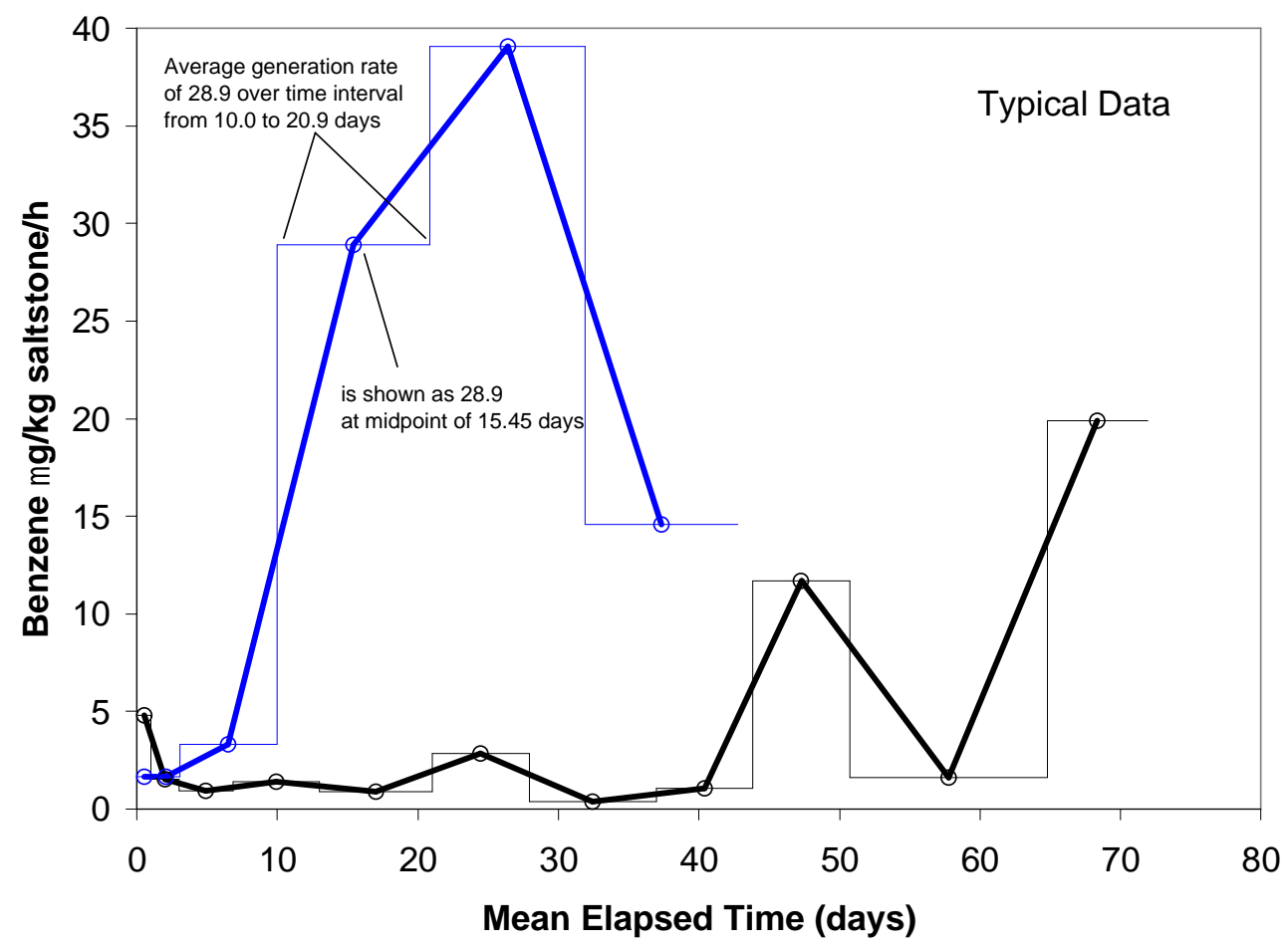

Figure 3-1. Graphic representation of integrated (averaged) release rate data.

The size of the vessels and the sampling and analysis methodology were tailored to be most accurate in the TRC region. Samples with > $200 \mathrm{ng}$ benzene/injection are greater than the highest calibration point on the GC. This mass of benzene corresponds to approximately $2 \mu \mathrm{g}$ flammable gas $/ \mathrm{kg}$ saltstone/h. The linear range of the GC calibration extends to values that correspond to $400 \mathrm{ng}$ benzene/injection. Linearity to $400 \mathrm{ng}$ benzene/injection is demonstrated by periodic GC 
injections of $2 \mu \mathrm{L}$ of $200 \mu \mathrm{g} / \mathrm{mL}$ of benzene in methanol ${ }^{*}$. Samples that contain $400-2500 \mathrm{ng}$ benzene/injection are under-estimated (less conservative) due to the deviation from linearity of the GC. Samples containing > 2500 ng benzene/injection exceed the dynamic range of the GC (not all of the peak area is identified) and are therefore underreported. Injections containing 2500 ng of flammable gas correspond to an evolution rate of $\sim 25 \mu \mathrm{g}$ flammable gas $/ \mathrm{kg}$ saltstone $/ \mathrm{h}$. For the final report, these samples will either be diluted and reanalyzed or a method for determining an approximate peak area will be developed.

In some of the plots, data points exist that do not follow the general trend of the rest of the vessel data. These points will be evaluated further to determine their validity.

The experimental data are best described with a series of graphs comparing the benzene (and toluene) evolution rates.

\subsubsection{Benzene}

\subsubsection{Vessels at $95{ }^{\circ} \mathrm{C}$}

In the oven at $95{ }^{\circ} \mathrm{C}$, many of the vessels developed restricted flow or no flow through the sampling lines. Restricted flow in a vessel would be indicated by erratic or reduced benzene rates if the purge was not sufficient to completely sweep the benzene from the vessel. The "no flow" condition would be indicated by no measurable benzene recovery. Sampling of the $95{ }^{\circ} \mathrm{C}$ oven samples were suspended at 52 days due to suspected restricted flow conditions. On day 73, all of the hardware susceptible to developing restrictions was replaced. During the suspension of sampling, the samples remained at temperature. After the hardware was replaced, the vessels were sampled. Data collected prior to hardware upgrades may not provide a representative indication of the actual release rates and should been used with caution. As of this report, sample results after the resumption of sampling were not available.

Figure 3-2 plots of all of the radioactive test data for benzene at $95{ }^{\circ} \mathrm{C}$. The replicate vessels of $3000 \mathrm{mg} / \mathrm{L} \mathrm{TPB}(\mathrm{H})$ are consistent. Two of the replicates at $1000 \mathrm{mg} / \mathrm{L}(\mathrm{M})$ released benzene at a rate much higher than the $3000 \mathrm{mg} / \mathrm{L}$ vessels sample results. However, the third replicate at 1000 $\mathrm{mg} / \mathrm{L}$ has released almost no benzene. The replicates with $30 \mathrm{mg} / \mathrm{L} \mathrm{TPB}(\mathrm{L})$ had release rates that were consistently low and measurable. The same results plotted on a smaller scale are shown in Figure 3-3. The vessels with $3000 \mathrm{mg} / \mathrm{L}$ TPB are in the "range of concern". The benzene release from the vessels containing $30 \mathrm{mg} / \mathrm{L}$ TPB are near the "range of concern". The results for the $3000 \mathrm{mg} / \mathrm{L}$ TPB for the radioactive and simulant samples at $95{ }^{\circ} \mathrm{C}$ are compared in Figure 3-5. The radioactive and simulant samples contained similar amounts of saltstone. For the first 40 days of testing, the radioactive benzene release is consistent with two of the simulant replicates (simulant replicate "c" exhibited higher benzene release rates). A comparison of the radioactive and simulant results for the vessels made with $1000 \mathrm{mg} / \mathrm{L}$ TPB in Figure 3-6 show that the release rates observed in the radioactive vessels are similar to those measured in the simulant tests. However, the radioactive replicates " $a$ " and "b" reached the level $(\sim 20 \mu \mathrm{g} / \mathrm{L}$ saltstone grout/h) much sooner than the simulant. Figure 3-7 compares the radioactive and simulant results for vessels containing $30 \mathrm{mg} / \mathrm{L} \mathrm{TPB}$ at $95{ }^{\circ} \mathrm{C}$. The blanks (saltstone vessels prepared without TPB) and vessels containing $30 \mathrm{mg} / \mathrm{L} \mathrm{TPB}$ are shown in Figure 3-8.

In addition to the "standard" vessels prepared with $3000 \mathrm{mg} / \mathrm{L}$ TPB, two vessels with approximately $3 \mathrm{x}$ the surface area were tested. To provide a direct surface area comparison, the

\footnotetext{
Supelco $48617200 \mu \mathrm{g} / \mathrm{mL}$ of benzene in methanol.
} 
$3 \mathrm{x}$ surface area vessels were prepared with approximately the same amount of saltstone. The benzene release rate for vessels with different surface area to volume $(\mathrm{SA} / \mathrm{V})$ ratios is plotted in Figure 3-4. Vessels with greater surface area exhibit higher benzene release rates. The increase in benzene release suggests that the evolution rate is likely to be transport (diffusion) limited at $95{ }^{\circ} \mathrm{C}$.

\subsubsection{Vessels at $75{ }^{\circ} \mathrm{C}$}

The benzene release from vessels held at $75{ }^{\circ} \mathrm{C}$ was as expected in that vessels containing greater quantities of TPB released more benzene than vessels with lesser amounts of TPB, Figure 3-9. It should also be noted that the vessels prepared with $3000 \mathrm{mg} / \mathrm{L}$ TPB salt solution exhibited benzene release rates near the "range of concern". In Figure 3-10 through Figure 3-12, the radioactive and simulant results for each of the TPB concentrations are compared. In the time frame evaluated, there exists good correspondence between the radioactive and simulant data. The benzene release from the "blank" at $75^{\circ} \mathrm{C}$ is shown in Figure 3-13 with the results from vessels containing $30 \mathrm{mg} / \mathrm{L} \mathrm{TPB}$ for comparison.

\subsubsection{Vessels at $25^{\circ} \mathrm{C}$}

All of the results for the radioactive samples held at $25{ }^{\circ} \mathrm{C}$ have benzene release rates below the TRC, Figure 3-14. Vessels with the greater surface area released benzene at a greater rate than the vessels with "standard" surface areas. The effect of surface area at $25^{\circ} \mathrm{C}$ is less than the effect observed at $95{ }^{\circ} \mathrm{C}$. Comparisons of the radioactive and simulant results for vessels prepared with $3000 \mathrm{mg} / \mathrm{L}$ TPB salt solution show good agreement in benzene release rates, Figure 3-15. Similar behavior was observed at the other TPB concentrations, Figure 3-16 and Figure 3-17. The benzene release from the "blanks" at $25{ }^{\circ} \mathrm{C}$ is shown in Figure 3-18 with the results from vessels containing $30 \mathrm{mg} / \mathrm{L}$ TPB for comparison.

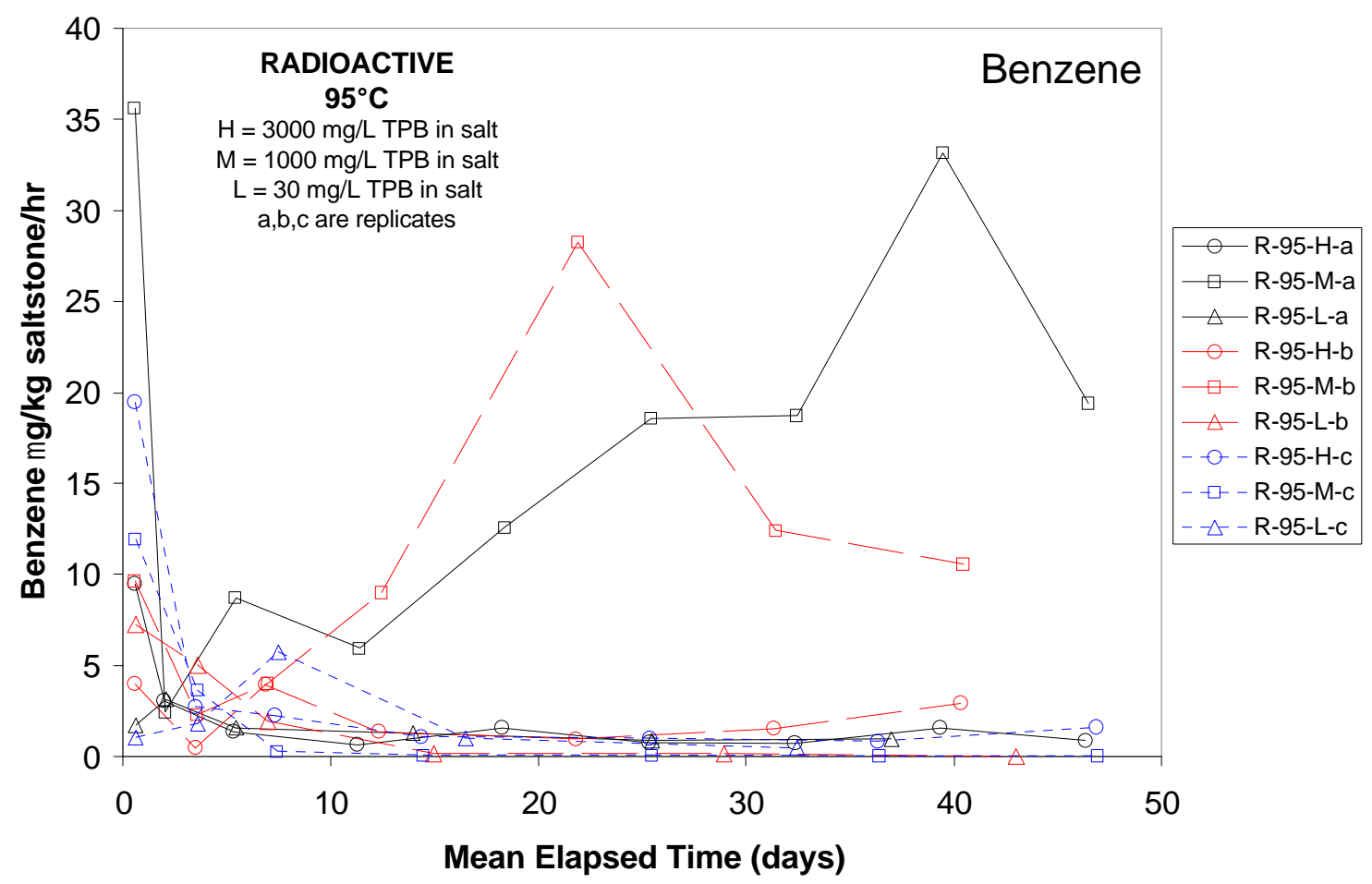

Figure 3-2. Benzene release from radioactive samples at $95{ }^{\circ} \mathrm{C}$. 
WSRC-TR-2005-00256

Revision 0

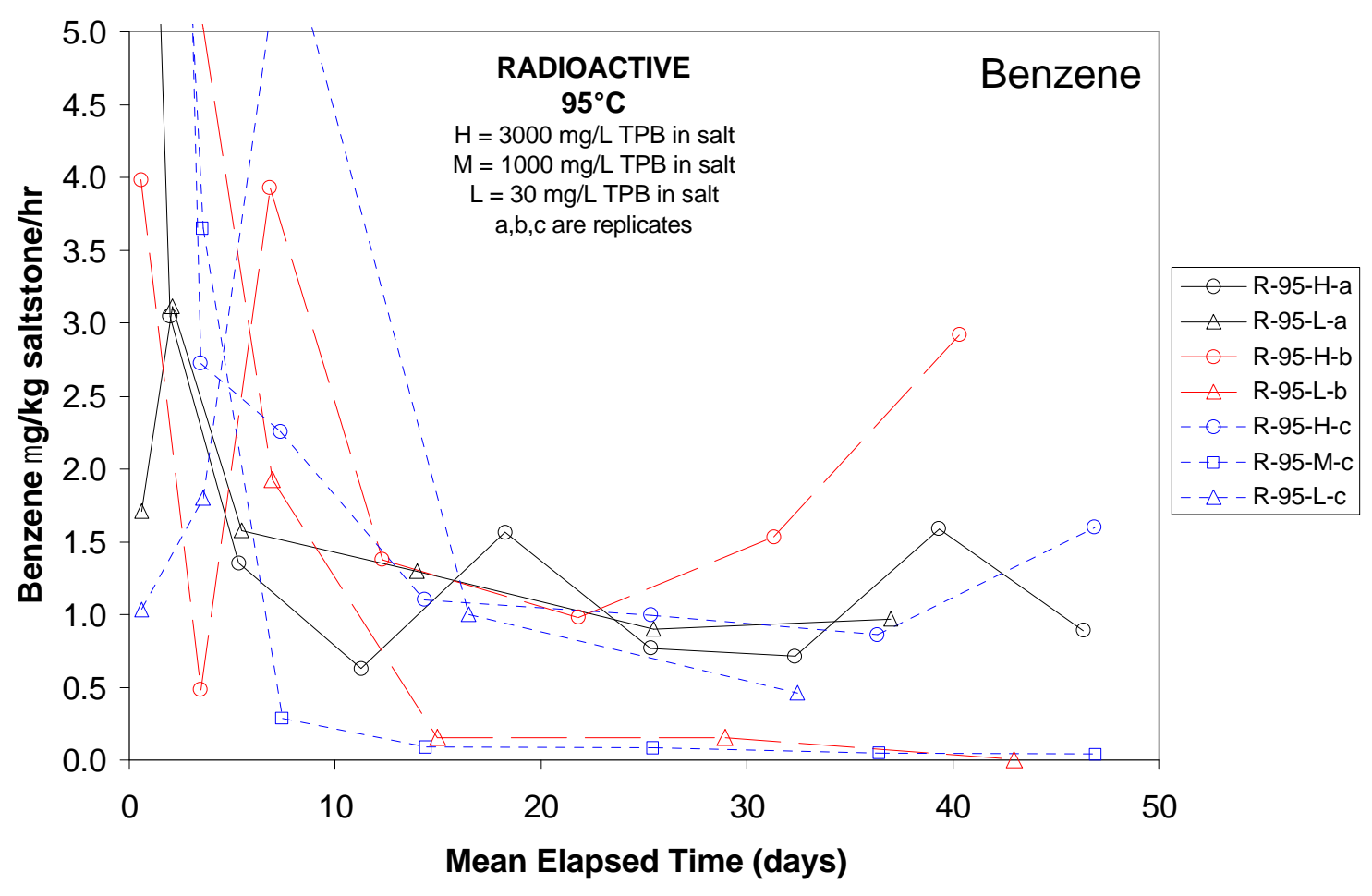

Figure 3-3. Results of Figure 3-2 expanded to show more detail in the lower release rates.

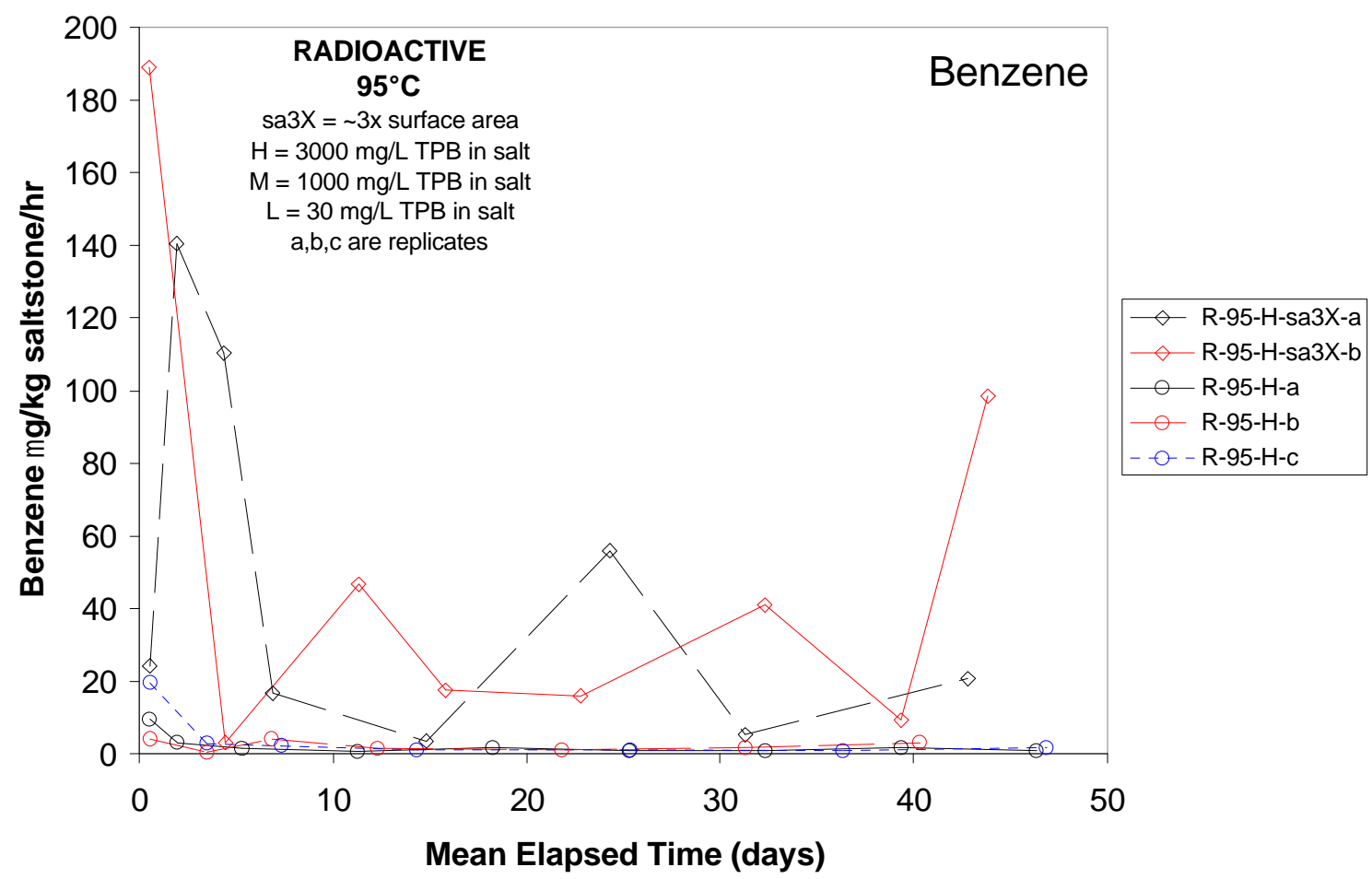

Figure 3-4. Benzene release of radioactive samples with different surface areas. 
WSRC-TR-2005-00256

Revision 0

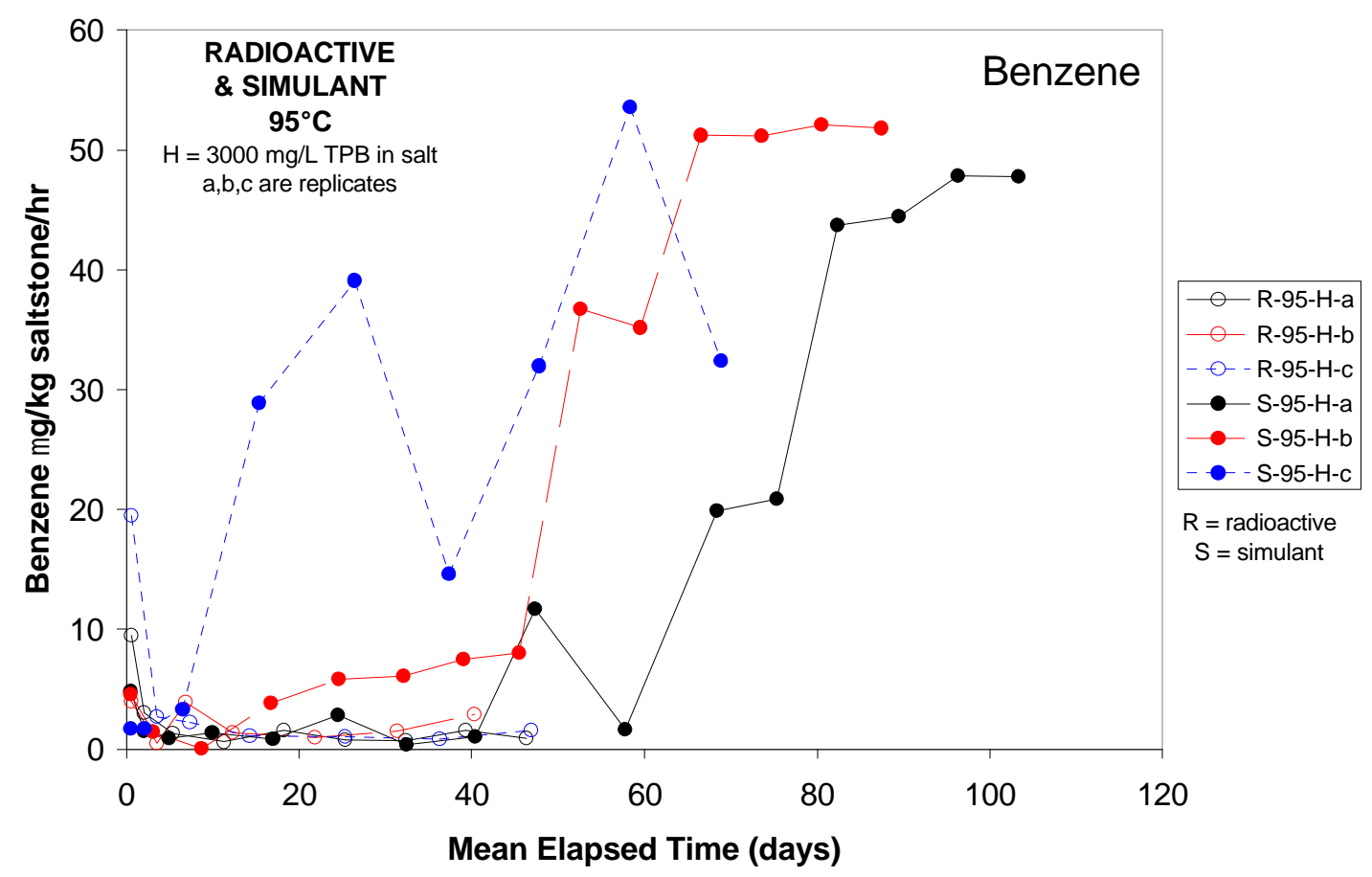

Figure 3-5. Comparison of benzene release from radioactive and simulant tests at $95{ }^{\circ} \mathrm{C}$, $3000 \mathrm{mg} / \mathrm{L}$ TPB.

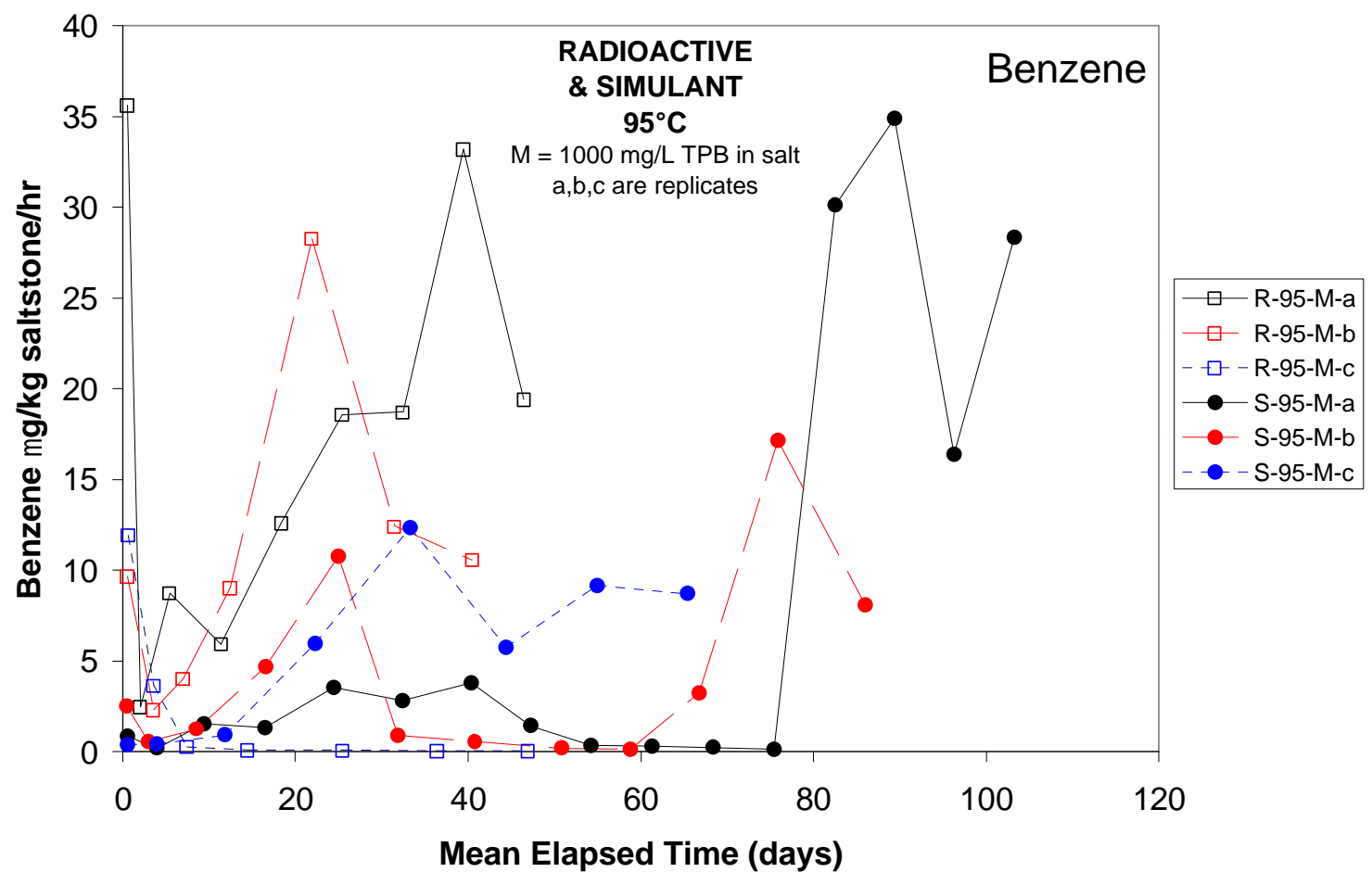

Figure 3-6. Comparison of benzene release from radioactive and simulant tests at $95{ }^{\circ} \mathrm{C}$, $1000 \mathrm{mg} / \mathrm{L}$ TPB. 
WSRC-TR-2005-00256

Revision 0

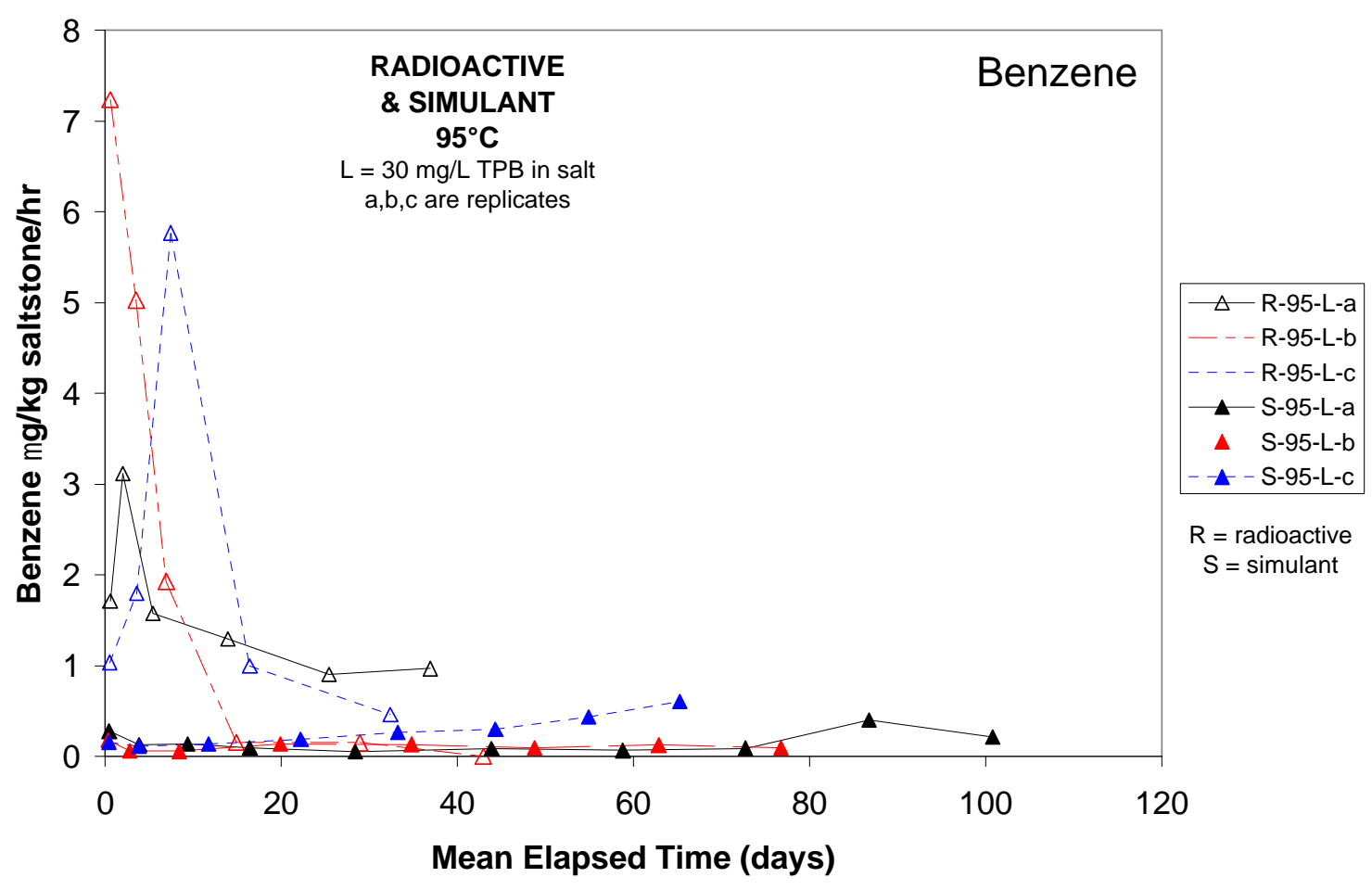

Figure 3-7. Comparison of benzene release from radioactive and simulant tests at $95{ }^{\circ} \mathrm{C}$, $30 \mathrm{mg} / \mathrm{L}$ TPB.

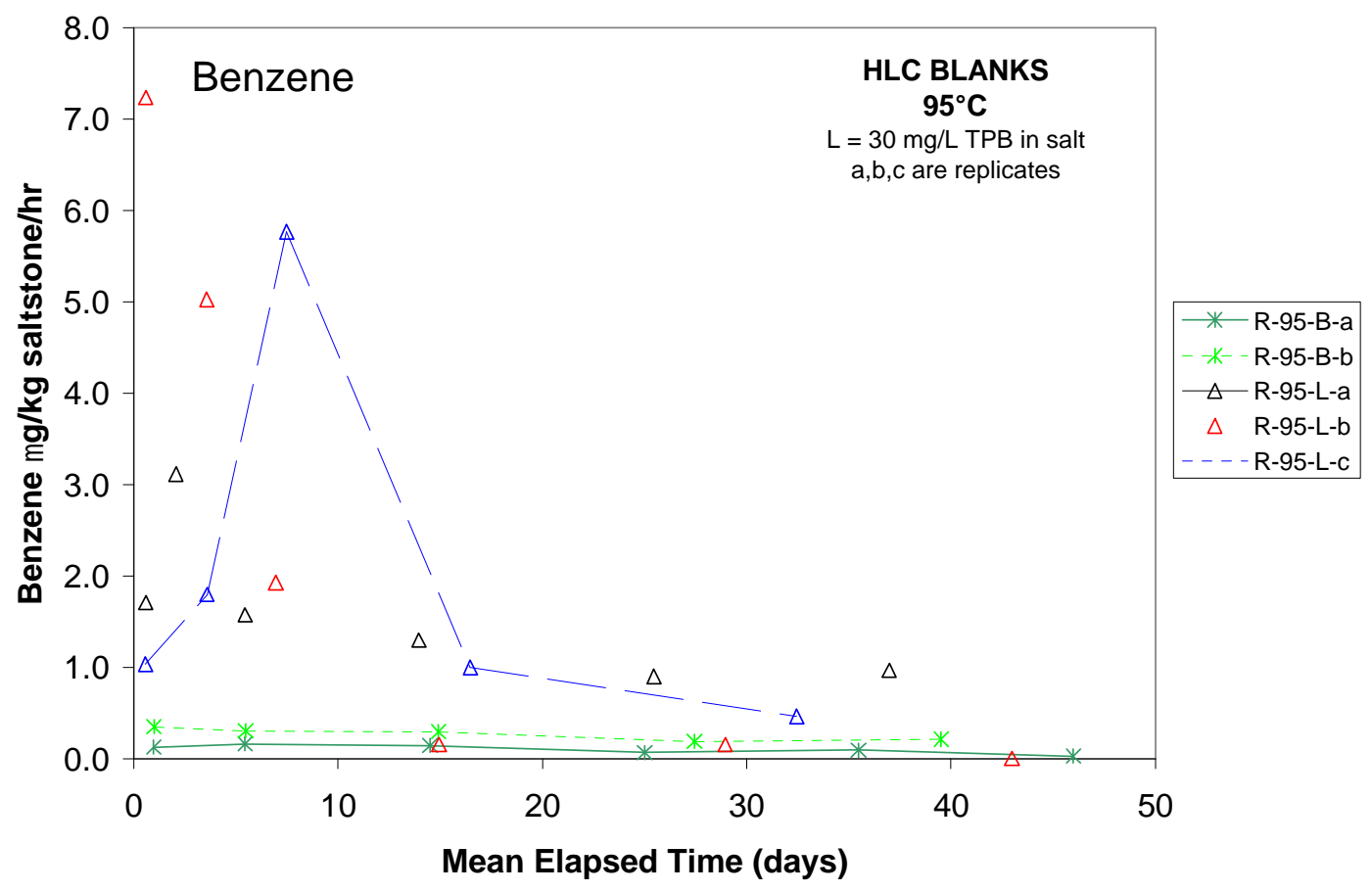

Figure 3-8. Comparison of benzene release from "blanks" at $95{ }^{\circ} \mathrm{C}$ to vessels containing $30 \mathrm{mg} / \mathrm{L}$ TPB. 
WSRC-TR-2005-00256

Revision 0

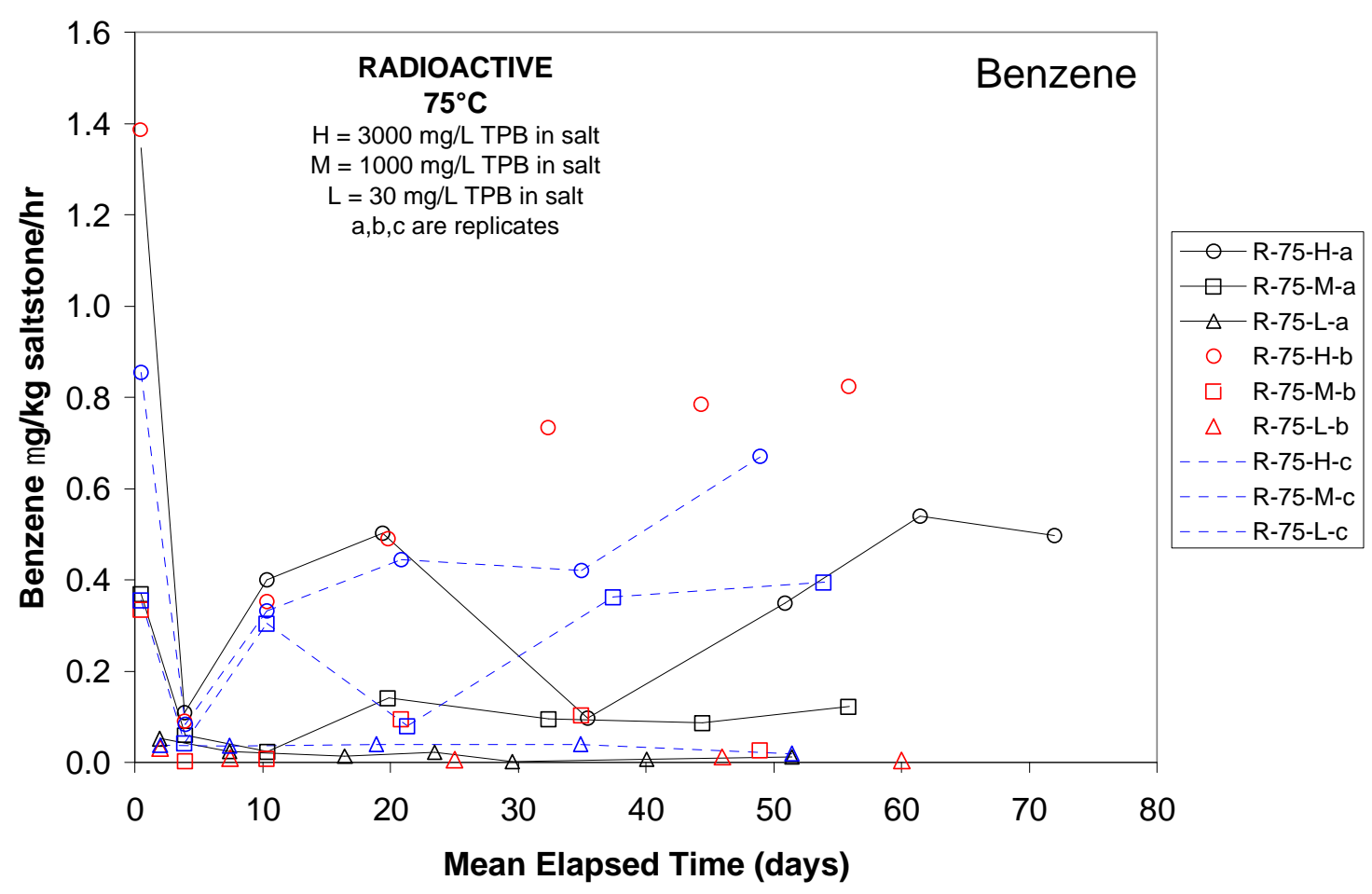

Figure 3-9. Benzene release from vessels at $75^{\circ} \mathrm{C}$ containing TPB.

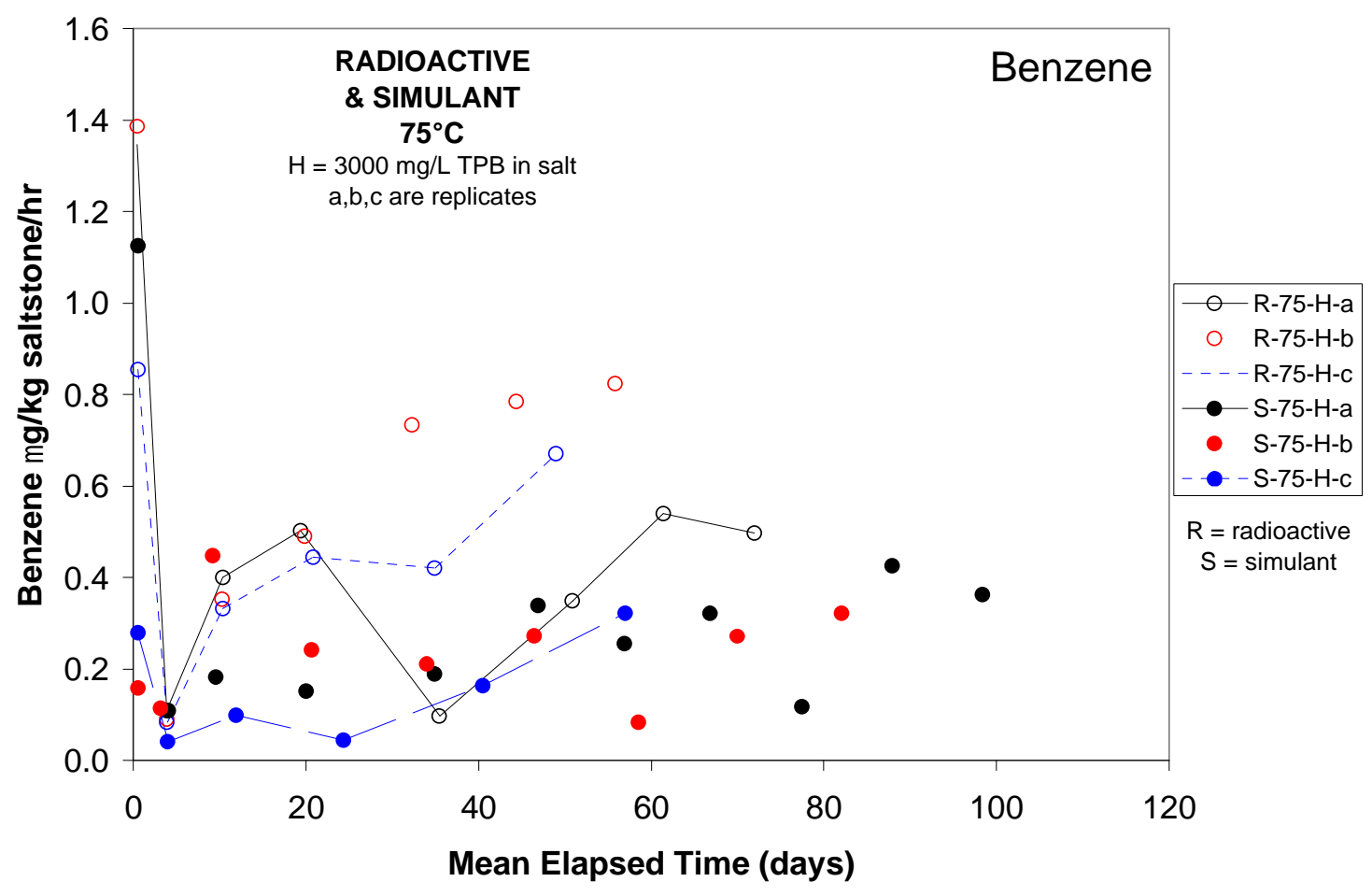

Figure 3-10. Comparison of benzene release from radioactive and simulant tests at $75{ }^{\circ} \mathrm{C}$, $3000 \mathrm{mg} / \mathrm{L}$ TPB. 
WSRC-TR-2005-00256

Revision 0

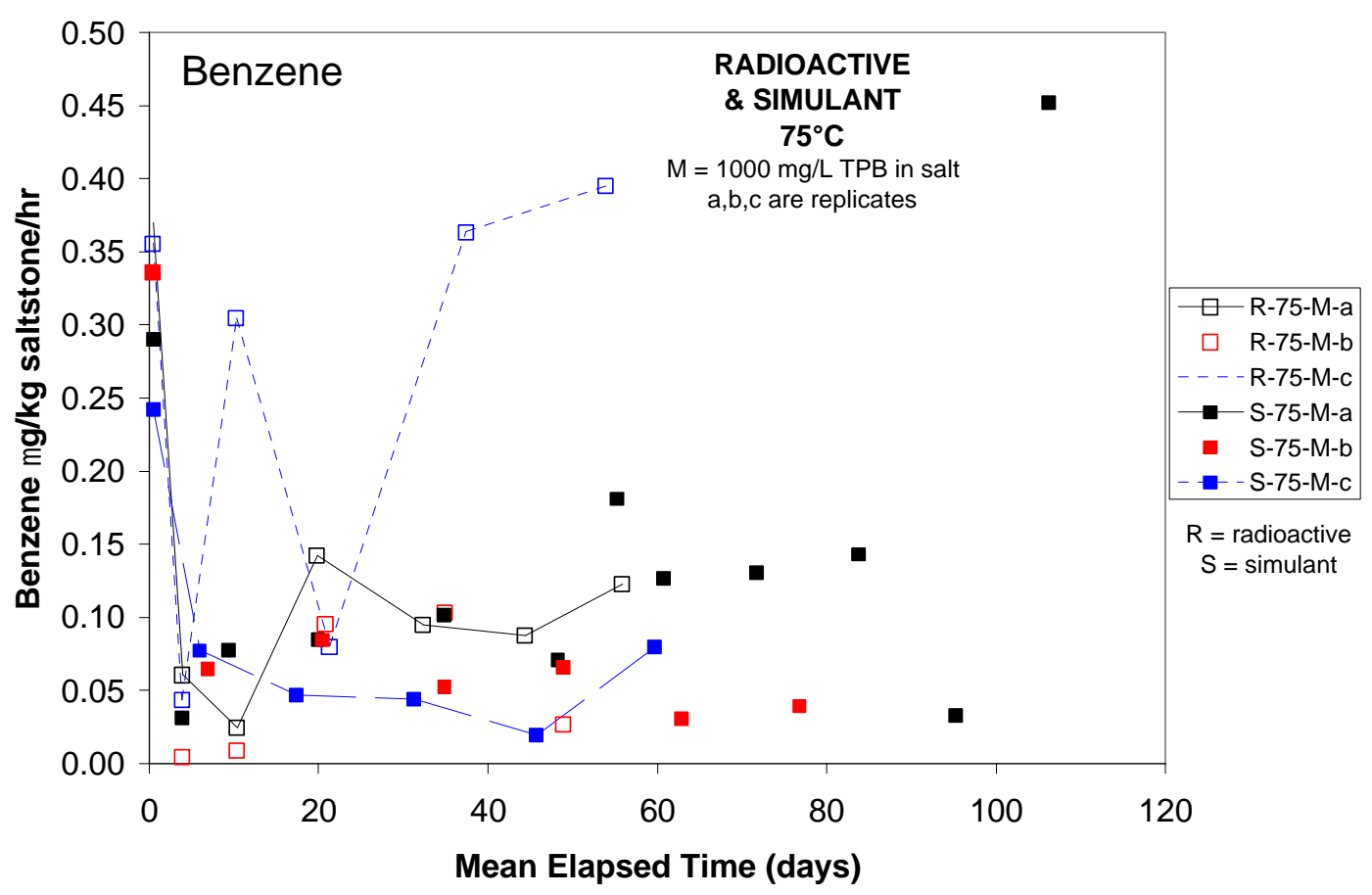

Figure 3-11. Comparison of benzene release from radioactive and simulant tests at $75^{\circ} \mathrm{C}, 1000 \mathrm{mg} / \mathrm{L}$ TPB.

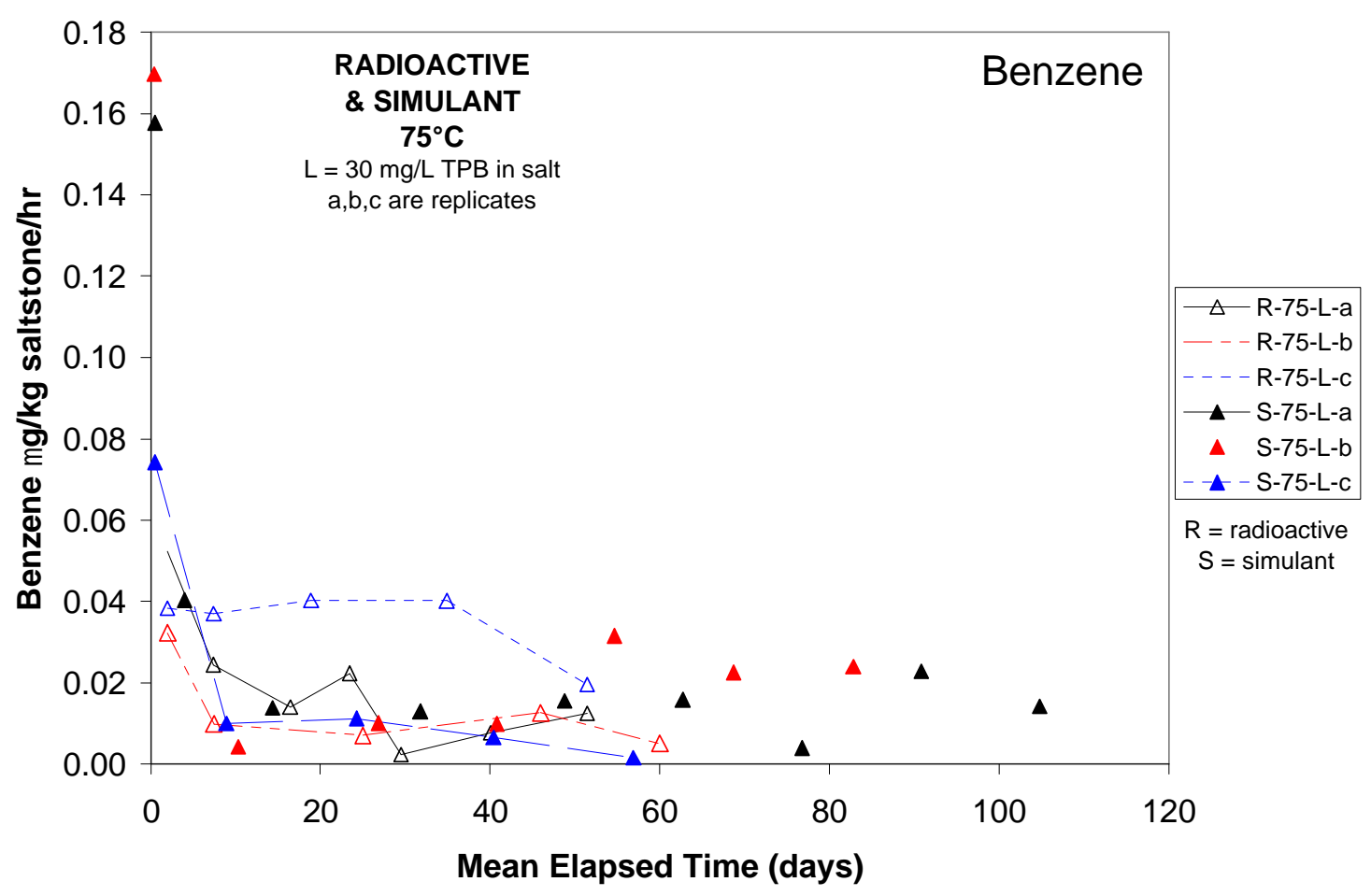

Figure 3-12. Comparison of benzene release from radioactive and simulant tests at $75{ }^{\circ} \mathrm{C}$, $30 \mathrm{mg} / \mathrm{L}$ TPB. 
WSRC-TR-2005-00256

Revision 0

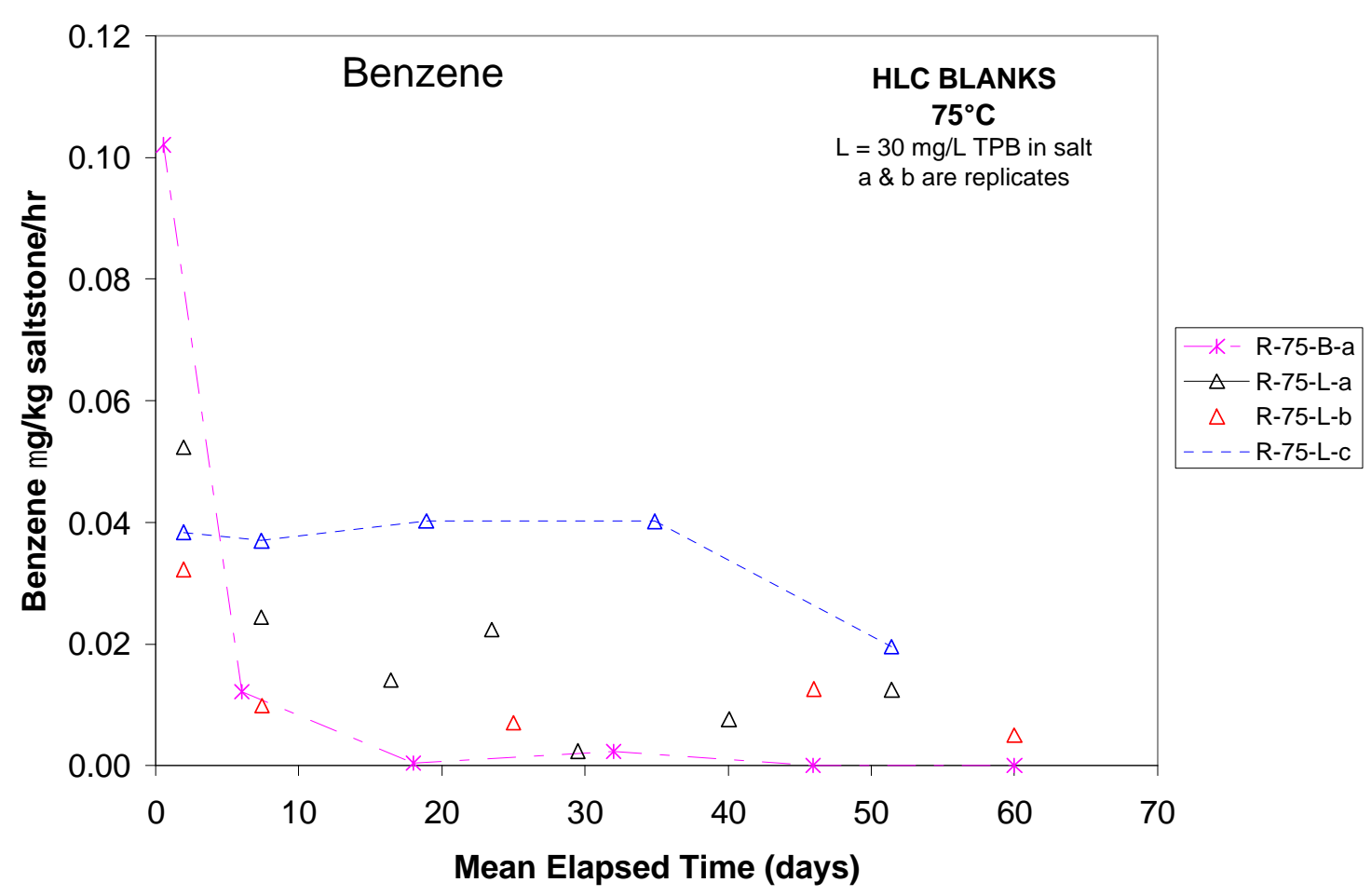

Figure 3-13. Comparison of benzene release from "blank" at $75^{\circ} \mathrm{C}$ to vessels containing $30 \mathrm{mg} / \mathrm{L}$ TPB.

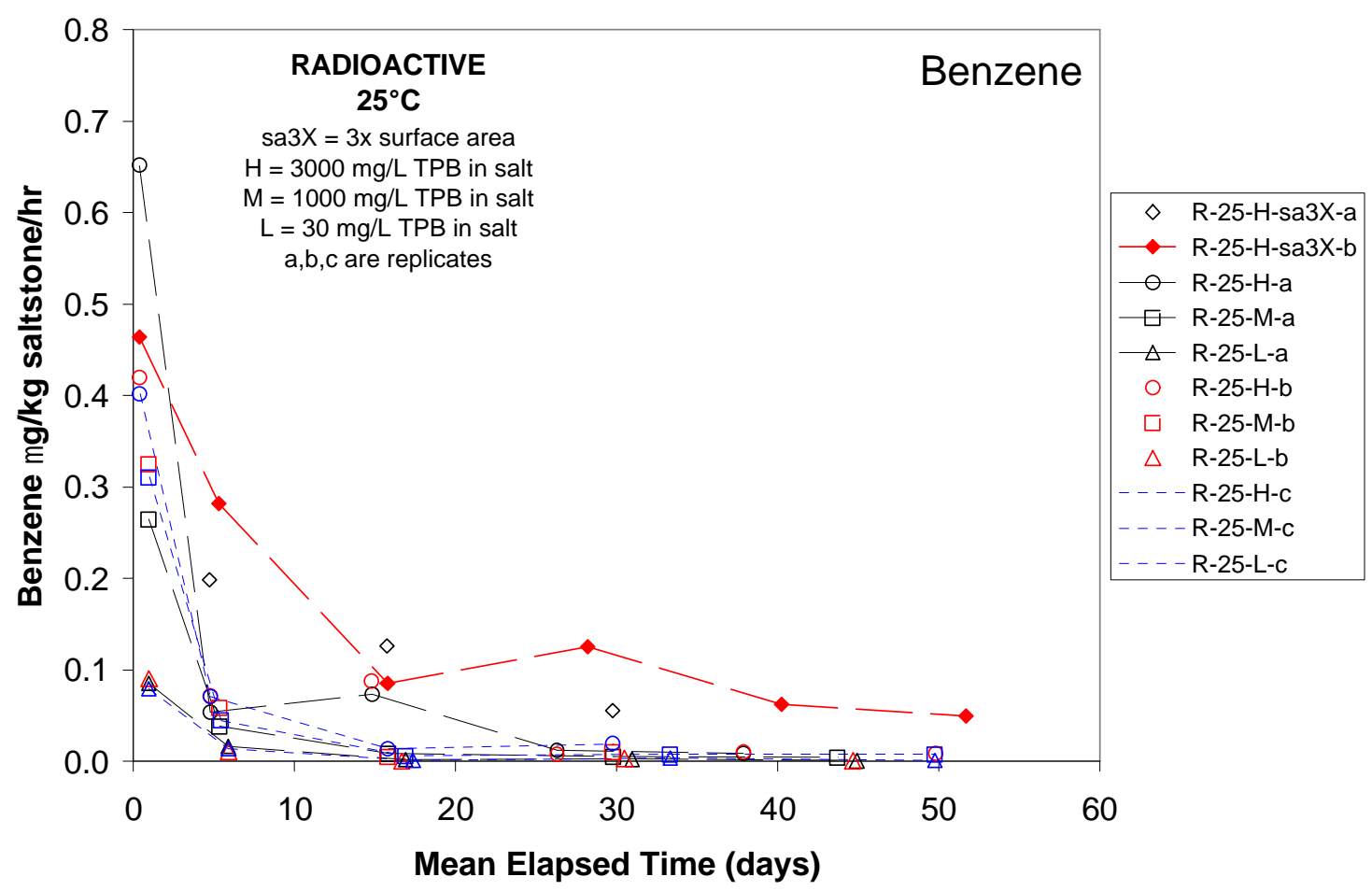

Figure 3-14. Benzene release from vessels at $25{ }^{\circ} \mathrm{C}$ containing TPB. 
WSRC-TR-2005-00256

Revision 0

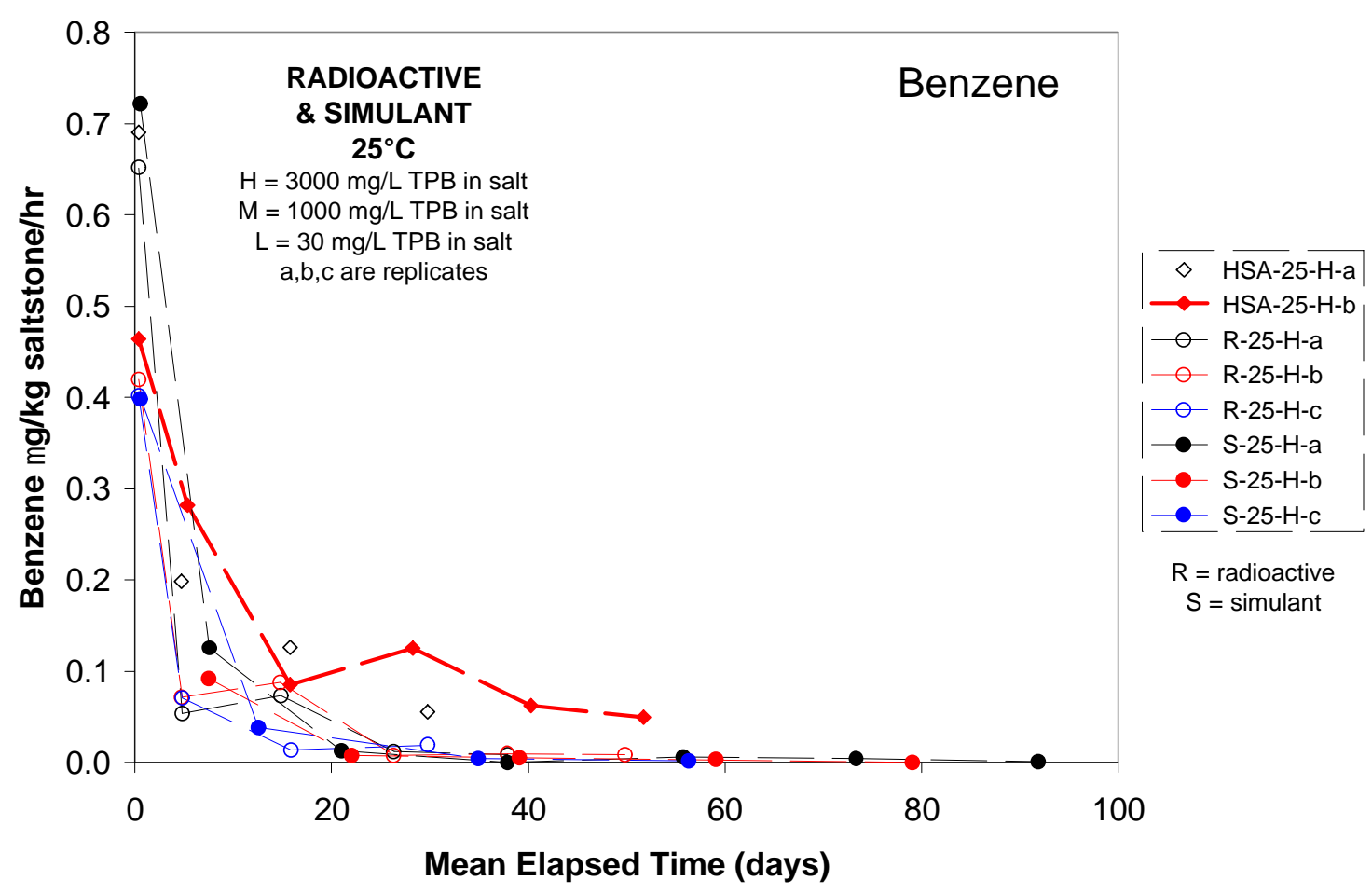

Figure 3-15. Comparison of benzene release from radioactive and simulant tests at $25{ }^{\circ} \mathrm{C}$, $3000 \mathrm{mg} / \mathrm{L}$ TPB.

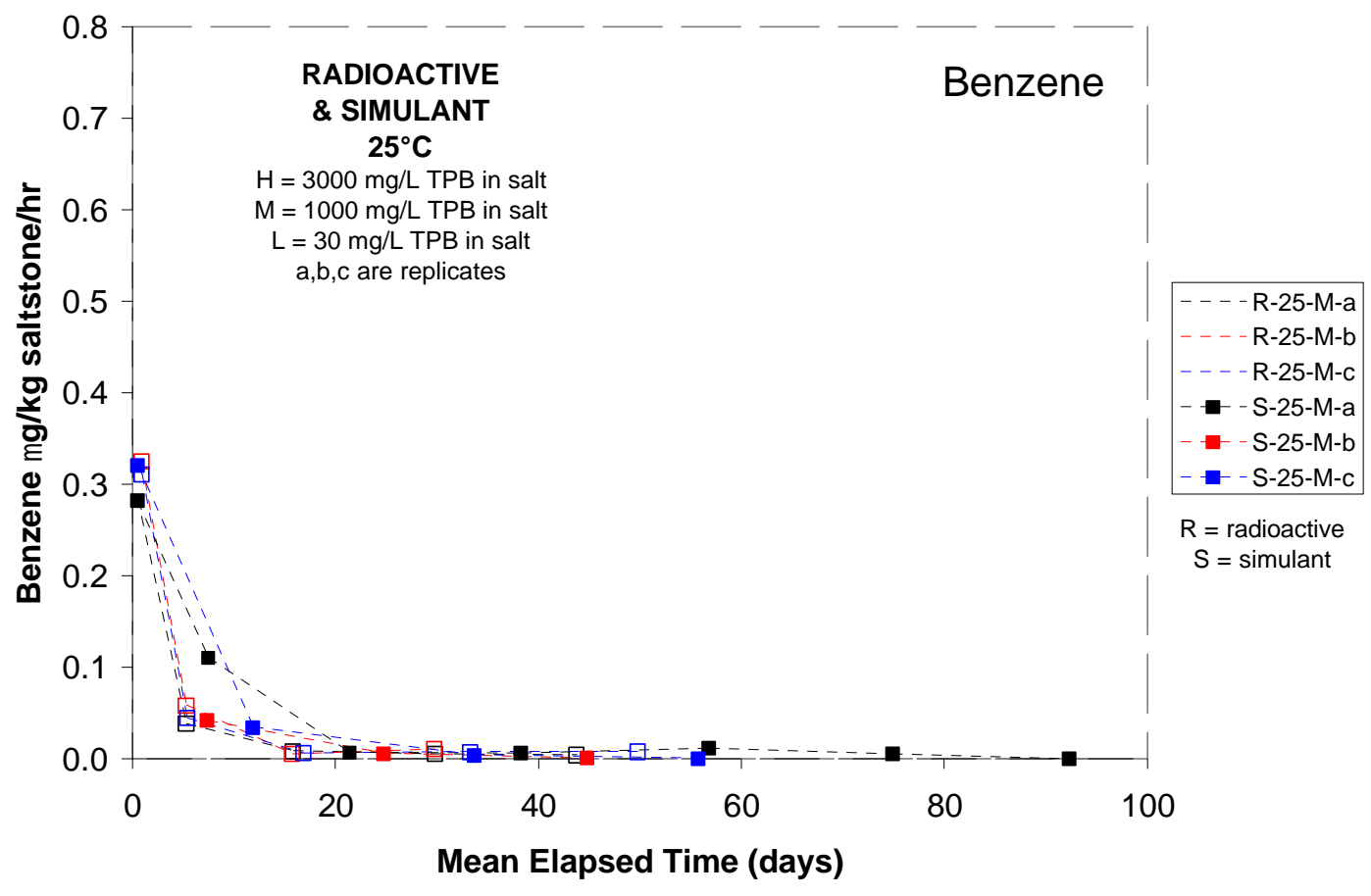

Figure 3-16. Comparison of benzene release from radioactive and simulant tests at $25{ }^{\circ} \mathrm{C}$, $1000 \mathrm{mg} / \mathrm{L}$ TPB. 
WSRC-TR-2005-00256

Revision 0

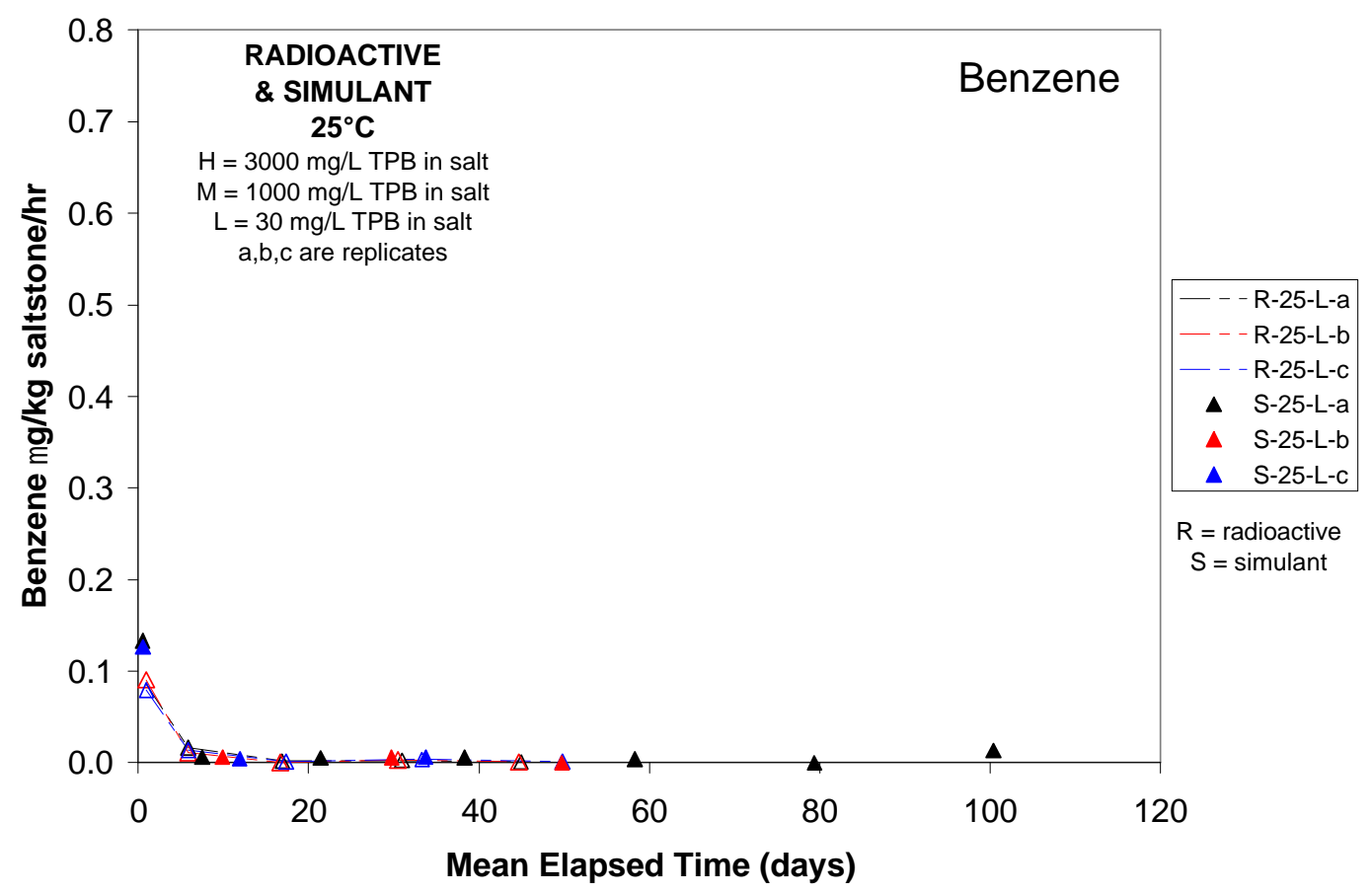

Figure 3-17. Comparison of benzene release from radioactive and simulant tests at $25{ }^{\circ} \mathrm{C}$, $30 \mathrm{mg} / \mathrm{L}$ TPB.

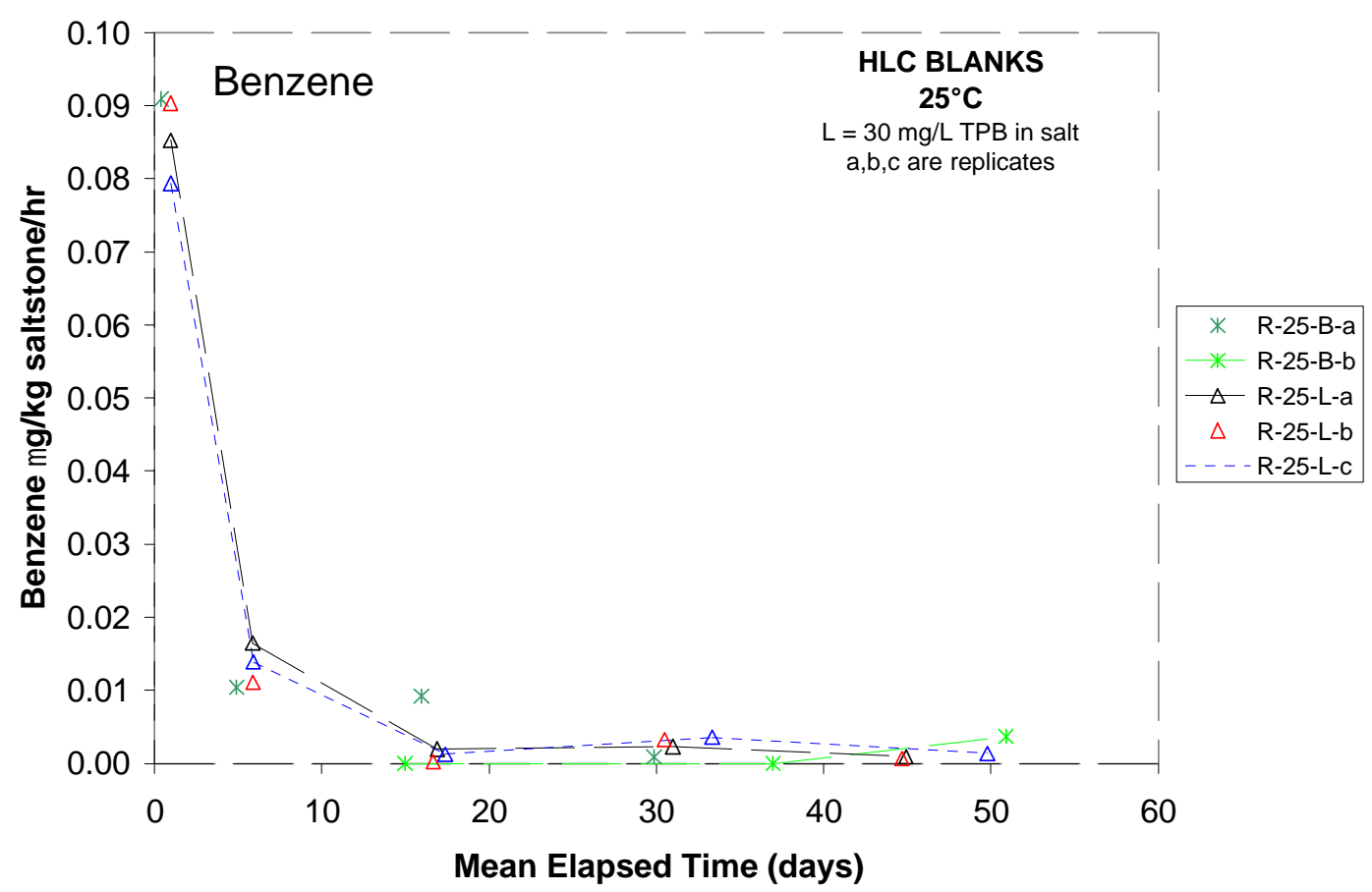

Figure 3-18. Comparison of benzene release from "blanks" at $25{ }^{\circ} \mathrm{C}$ to vessels containing $30 \mathrm{mg} / \mathrm{L}$ TPB. 


\subsubsection{Toluene}

The evolution of toluene is shown in Figure 3-19 through Figure 3-21. The recovery of similar species (toluene [methylbenzene] is very similar to benzene) should be about the same because the affinity of the carbon sample tubes for toluene is supposed to be essentially the same as that for benzene. There is no reason why the recovery of toluene from the standard vessels would be expected to be any different than the recovery of benzene.

The results for toluene indicate that the source of fly ash may be the most significant factor affecting the emission rate. In all cases, the initial higher rate quickly diminishes within about 5 days. The steady state rates were all below the emission TRC. Toluene does not appear to be generated from decomposition of the TPB; if it were, there should be TPB concentration dependence, and no dependence was observed.

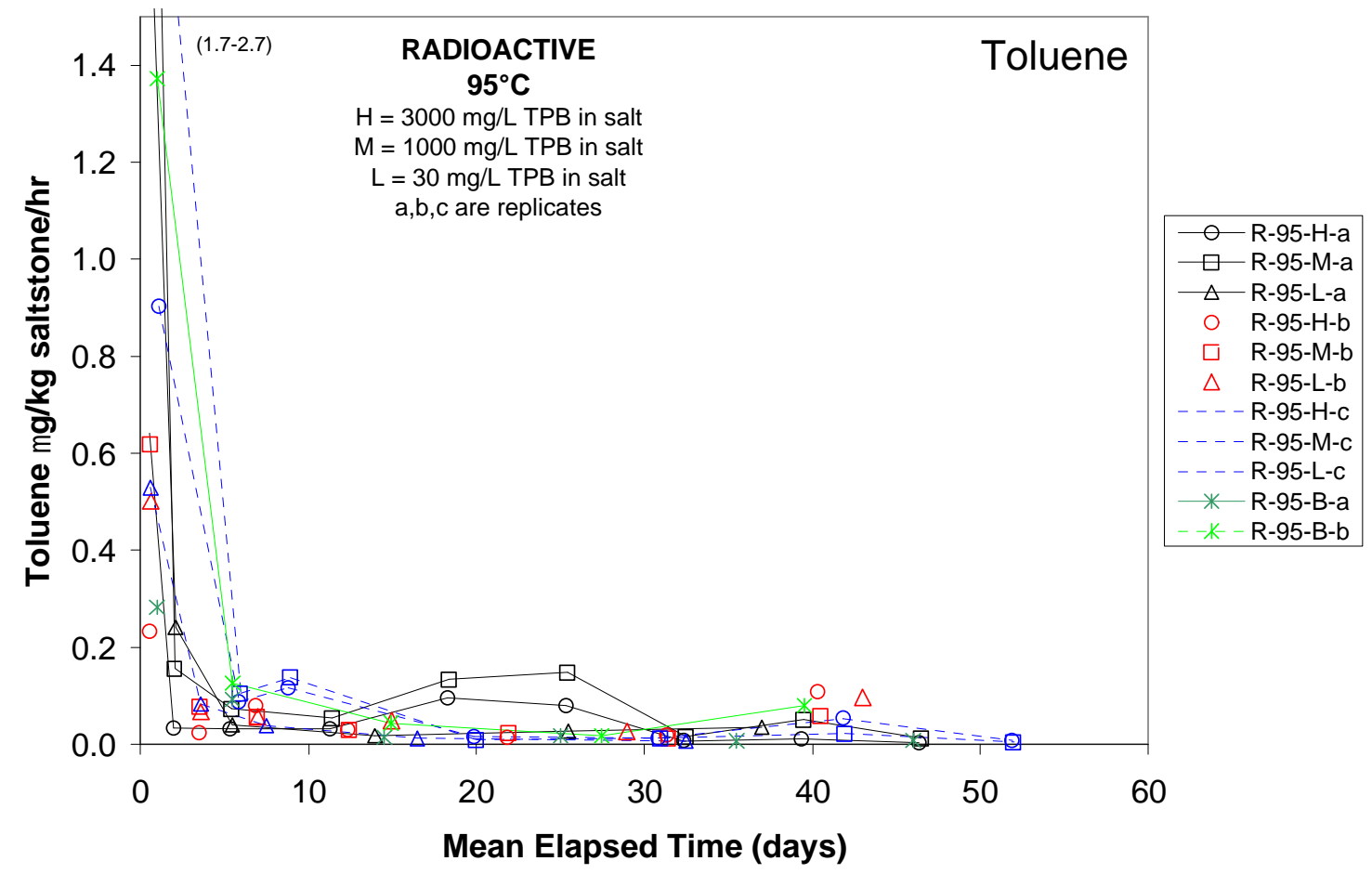

Figure 3-19. Toluene release from radioactive samples at $95{ }^{\circ} \mathrm{C}$. 
WSRC-TR-2005-00256

Revision 0

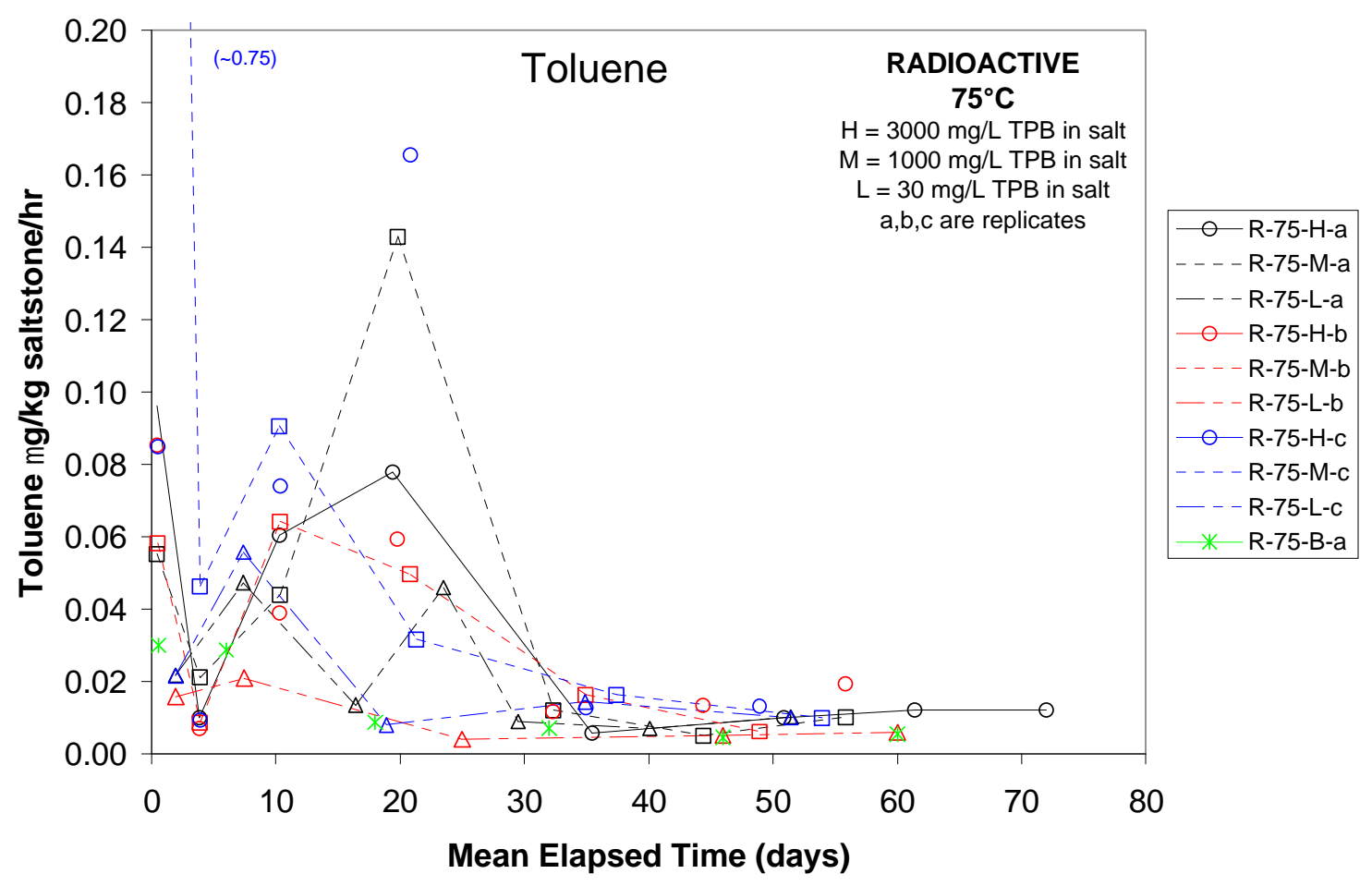

Figure 3-20. Toluene release from radioactive samples at $75^{\circ} \mathrm{C}$.

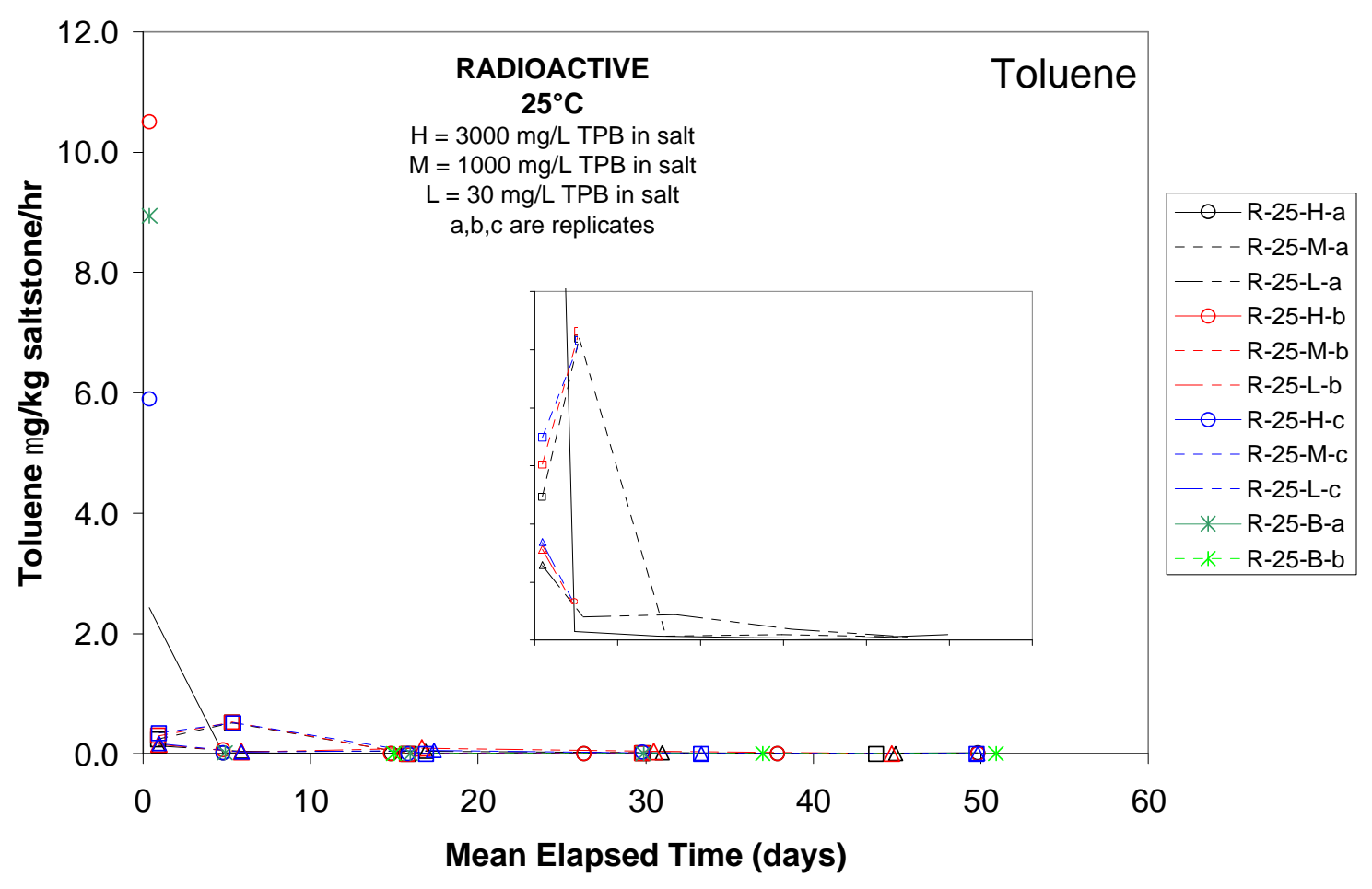




\subsection{SUMMARY \& CONCLUSIONS (TO DATE)}

The benzene evolution rates approximate a trend that is directly proportional to both temperature and TPB concentration. The benzene release rates from $1000 \mathrm{mg} / \mathrm{L} \mathrm{TPB}$ at $95{ }^{\circ} \mathrm{C}$ and $3000 \mathrm{mg} / \mathrm{L}$ TPB at $75{ }^{\circ} \mathrm{C}$ and $95{ }^{\circ} \mathrm{C}$ exceeded the recovery-adjusted $0.9 \mu \mathrm{g} / \mathrm{kg}$ saltstone $/ \mathrm{h}$ TRC $(2.5 \mu \mathrm{g} / \mathrm{L}$ saltstone/h), while all other conditions resulted in benzene release rates below the TRC. The toluene evolution rates for several samples exceeded the TRC initially, but all dropped below the TRC within 2-5 days. The toluene emissions appear to be mainly dependent on the fly ash and are independent of the TPB level, indicating that toluene is not generated from TPB.

Although not a part of this report, the upward trend of simulant data observed warrants further testing and analyses. Additional simulant results to address the surface area to volume portion of the task are also being collected. 
WSRC-TR-2005-00256

Revision 0

\subsection{REFERENCES}

1.T.E. Chandler, "Determine Benzene Generation Rates from Saltstone at Elevated Temperatures," Task Technical Request SSF-TTR-2004-0005, (2004).

2.T.E. Chandler, Presentation at "Benzene Analysis Brainstorm Meeting," 11/1/2004.

3.M.S. Hay, "Literature Review of the Effects of Tetraphenylborate on Saltstone Grout: Benzene Evolution and TCLP Performance,"WSRC-TR-2004-00383, (2004).

4. A.D. Cozzi, D.A. Crowley, J.M. Duffey, R.E. Eibling, T.M. Jones, A.R. Marinik, J.C. Marra, and J.R. Zamecnik, "Measurements of Flammable Gas Generation from Saltstone Containing Simulated Tank 48H Waste (Interim Report), WSRC-TR-2005-00180, (2005).

5.NIOSH method 1501, Issue 3, "Hydrocarbons, Aromatic" March 2003.

6.R.F. Swingle, "Results of Analyses of Tank 23H and 24H Saltstone WAC Samples HTK-521 HTK-528," WSRC-TR-2003-00112, (2003).

7.A.D. Cozzi, E-mail to T.E. Chandler, 1/11/2005.

8.D.P. Lambert, T.B. Peters, M.E. Stallings, and S.D. Fink, "Analysis of Tank 48H Samples HTF-E-03-73 (June 03, 2003) and HTF-E-03-127 (September 17, 2003)," WSRC-TR-200300720, Revision 0 (2003).

9.A.D. Cozzi and J.R. Zamecnik, "Tetraphenylborate Decomposition in Saltstone," WSRC-RP2004-00749, Revision 0 (2004).

10. D.P. Lambert, "Initial Tank 48H March 05 Sample Results," SRNL-WPT-2005-00069, May 2005.

11. A.D. Cozzi, "Formulation Development for Processing Tank 48H in Saltstone," WSRC-TR2004-00477, Revision 0 (2004). 